\title{
¿Severe Convective Storms across Europe and the United States. Part I: Climatology of Lightning, Large Hail, Severe Wind, and Tornadoes
}

\author{
Mateusz Taszarek, ${ }^{\mathrm{a}, \mathrm{b}}$ John T. Allen, ${ }^{\mathrm{c}}$ Pieter Groenemeijer, ${ }^{\mathrm{d}, \mathrm{e}}$ Roger Edwards, ${ }^{\mathrm{f}}$ Harold E. Brooks, ${ }^{\mathrm{b}, \mathrm{g}}$ \\ VANNA CHMIELEWSKI, ${ }^{\text {h,b }}$ AND SVEN-ERIK ENNO ${ }^{\mathrm{i}}$ \\ ${ }^{\text {a }}$ Department of Meteorology and Climatology, Adam Mickiewicz University, Poznań, Poland; ${ }^{\mathrm{b}}$ National Severe Storms \\ Laboratory, Norman, Oklahoma; ${ }^{\mathrm{c}}$ Central Michigan University, Mount Pleasant, Michigan; ${ }^{\mathrm{d}}$ European Severe Storms Laboratory- \\ Science and Training, Wiener Neustadt, Austria; ${ }^{\mathrm{e}}$ European Severe Storms Laboratory, Wessling, Germany; ${ }^{\mathrm{f}}$ National Weather \\ Service Storm Prediction Center, Norman, Oklahoma; ${ }^{\mathrm{g}}$ School of Meteorology, University of Oklahoma, Norman, Oklahoma; \\ ${ }^{\mathrm{h}}$ Cooperative Institute for Mesoscale Meteorological Studies, University of Oklahoma, Norman, Oklahoma; ${ }^{\mathrm{i}}$ Met Office, Exeter, \\ United Kingdom
}

(Manuscript received 13 May 2020, in final form 2 August 2020)

\begin{abstract}
As lightning-detection records lengthen and the efficiency of severe weather reporting increases, more accurate climatologies of convective hazards can be constructed. In this study we aggregate flashes from the National Lightning Detection Network (NLDN) and Arrival Time Difference long-range lightning detection network (ATDnet) with severe weather reports from the European Severe Weather Database (ESWD) and Storm Prediction Center (SPC) Storm Data on a common grid of $0.25^{\circ}$ and 1-h steps. Each year approximately $75-200$ thunderstorm hours occur over the southwestern, central, and eastern United States, with a peak over Florida (200-250 h). The activity over the majority of Europe ranges from 15 to $100 \mathrm{~h}$, with peaks over Italy and mountains (Pyrenees, Alps, Carpathians, Dinaric Alps; 100$150 \mathrm{~h}$ ). The highest convective activity over continental Europe occurs during summer and over the Mediterranean during autumn. The United States peak for tornadoes and large hail reports is in spring, preceding the maximum of lightning and severe wind reports by 1-2 months. Convective hazards occur typically in the late afternoon, with the exception of the Midwest and Great Plains, where mesoscale convective systems shift the peak lightning threat to the night. The severe wind threat is delayed by $1-2 \mathrm{~h}$ compared to hail and tornadoes. The fraction of nocturnal lightning over land ranges from $15 \%$ to $30 \%$ with the lowest values observed over Florida and mountains $(\sim 10 \%)$. Wintertime lightning shares the highest fraction of severe weather. Compared to Europe, extreme events are considerably more frequent over the United States, with maximum activity over the Great Plains. However, the threat over Europe should not be underestimated, as severe weather outbreaks with damaging winds, very large hail, and significant tornadoes occasionally occur over densely populated areas.
\end{abstract}

KEYWORDS: Lightning; Tornadoes; Climatology; Convective storms; Hail; Seasonal cycle

\section{Introduction}

\section{a. Overview}

Convective storms are common phenomena during spring and summer across both Europe and the United States, and frequently produce severe weather and societal impacts (Brooks et al. 2018). Each year, hundreds of lightning, large hail, damaging wind, tornado, and flash flood events occur over both continents, causing fatalities and considerable damage to infrastructure (Doswell 2003; Ashley 2007; Ashley and Black 2008; Piper et al. 2016; Terti et al. 2017). Knowledge of the spatiotemporal variability of severe thunderstorms is therefore valuable not only for national weather services, but also for risk modeling and the insurance industry.

Thunderstorms can be detected efficiently using automatic ground-based or satellite lightning detection systems (Cecil et al. 2015; Albrecht et al. 2016; Bedka et al. 2018; Galanaki

๑ Denotes content that is immediately available upon publication as open access.

Corresponding author: Mateusz Taszarek, mateusz.taszarek@ amu.edu.pl; mateusz.taszarek@noaa.gov et al. 2018), but severe local events, such as large hail or tornadoes, still require a reporting observer. The reliance on observers creates a spatial bias toward more populated areas, and introduces temporal inhomogeneity driven by a consistently increasing reporting efficacy (Verbout et al. 2006; Groenemeijer et al. 2017; Edwards et al. 2018; Allen 2018). Changes in reporting can be linked to the transition toward a so-called digital society that results from improvements to technology (e.g., mobile phone cameras and the widespread access to the Internet that allows severe weather to be documented and rapidly shared with others; Krennert et al. 2018; Graham and Dutton 2019). Social media have also promoted sharing of weather-related information and increased the interest in thunderstorms (Edwards et al. 2013; Elmore et al. 2014; Seimon et al. 2016; Holzer et al. 2017). As a result, more data describing the occurrence and impact of convective storms have been collected than ever before.

This remarkable increase in storm reports and rapid development of lightning detection networks has enabled the construction of more accurate climatologies of (severe) thunderstorms, and allowed analyses that over Europe were not possible at the

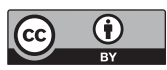

This article is licensed under a Creative Commons Attribution 4.0 license (http://creativecommons.org/ licenses/by/4.0/). 
beginning of the twenty-first century (Dotzek et al. 2009; Groenemeijer et al. 2017; Taszarek et al. 2019a). United States Storm Data has greater consistency over time, but even so the increasing reporting efficiency of weak tornadoes, large hail, and severe wind events can be observed over the last 20 years (e.g., Allen and Tippett 2015; Edwards et al. 2018). Although multiple attempts have been made to study the spatiotemporal variability of convective events across both Europe and the United States (including comparisons; Brooks 2009; Grünwald and Brooks 2011; Groenemeijer et al. 2017), no study has combined all observational datasets to compare the climatologies of lightning and storm observations across both continents.

\section{b. Observations of severe convective storms over Europe and the United States}

Severe storms have been recorded throughout history in both Europe and North America, starting in the classical period, and with a renewed interest arising in the nineteenth and early twentieth century (Dotzek 2003; Groenemeijer and Kühne 2014; Antonescu et al. 2016, 2019). During the socialist period in central and eastern parts of Europe from 1945 to 1989, information on catastrophic events was difficult to find, which has resulted in relatively few severe weather reports (Antonescu and Bell 2015; Taszarek and Gromadzki 2017; Brázdil et al. 2019). For the United States, regular climatological studies have appeared interspersed with case studies from a variety of observational data sources for hail, tornadoes, and damaging winds (e.g., Kelly et al. 1985; Grazulis 1991; Bentley and Mote 1998; Changnon 1999; Doswell et al. 2005). In recent years, the interest in severe storms has increased across Europe, with a large number of studies on severe wind events (Hamid 2012; Celiński-Mysław and Matuszko 2014; Mohr et al. 2017; Mathias et al. 2017, 2019; Taszarek et al. 2019b; Gatzen et al. 2020), hailstorms (Mohr et al. 2015; Nisi et al. 2016; Kahraman et al. 2016; Kunz et al. 2018; Trefalt et al. 2018; Kunz et al. 2020), and tornadoes (Chernokulsky and Shikhov 2018; Miglietta and Matsangouras 2018; Antonescu et al. 2018; Avgoustoglou et al. 2018; Pilguj et al. 2019; Chernokulsky et al. 2020). The first continuous pan-European data collection effort began with the operation of the European Severe Weather Database (ESWD) by the European Severe Storms Laboratory in 2006 (Dotzek et al. 2009; Groenemeijer et al. 2017). The ESWD integrated previously existing national datasets, and has since relied on a network of voluntary severe weather reporters spread across Europe. ESWD observations have seen a variety of applications, including developing panEuropean climatologies of severe thunderstorms (Taszarek et al. 2019a), tornadoes (Groenemeijer and Kühne 2014; Antonescu et al. 2016), and hail (Punge et al. 2014, 2017; Punge and Kunz 2016; Púčik et al. 2019).

Data collection efforts for severe storms for the United States have been based on several datasets, the largest presently being the Storm Prediction Center Storm Data (SPCSD), spanning 1950 to the present (Schaefer and Edwards 1999). Like the ESWD, SPCSD is highly reliant on observer density and availability, with a number of biases and inhomogeneities, which can generate challenges in constructing climatologies of convective hazards (Doswell et al. 2005; Verbout et al. 2006;
Blair et al. 2017; Allen et al. 2017; Edwards et al. 2018; Potvin et al. 2019). Nonetheless, the large size of this dataset has proven attractive in deriving severe thunderstorm climatologies and other operational applications (e.g., Thompson et al. 2003; Thompson et al. 2012; Johnson and Sugden 2014; Allen and Tippett 2015; Gropp and Davenport 2018; Coffer et al. 2019; Murillo and Homeyer 2019; Gensini et al. 2020).

Other observational records have been derived from insurance records and agricultural crop losses, but these records have been less commonly used, and are temporally incomplete (Changnon 1999; Kunz and Puskeiler 2010). Remote sensing data from both satellite and radar have become increasingly available in recent years, but not without the limitations of being indirect proxies, or being temporally or spatially limited due to coverage (Cintineo et al. 2012; Cecil and Blankenship 2012; Kunz and Kugel 2015; Puskeiler et al. 2016; Wapler 2017; Bedka et al. 2018; Schlie et al. 2019; Bang and Cecil 2019; Fluck et al. 2020). Nonetheless, while climatological information is plentiful, few efforts look at the distribution of severe thunderstorm hazards and lightning holistically.

\section{c. Aim of the study}

In this study we combine lightning data and severe weather reports over the period 1979-2018 for both Europe and the United States. By standardizing all datasets to a $0.25^{\circ}$ grid and 1-h step, we can derive and compare annual, diurnal, and spatial distributions of lightning, large hail, severe wind, and tornadoes across both domains. This approach allows derivation of conditional probabilities of specific severe weather types (given the occurrence of lightning) and better assessment of spatial reporting biases. A comparison of ESWD with the more complete SPCSD also allows a better evaluation of underreporting issues in European data. In addition, similarities and limitations of all datasets are discussed for both continents.

This study is divided into two parts. In this part we focus purely on the synthesis of observational datasets, while in the second part we combine these data with their reanalysisderived environments to evaluate the underlying relationships between severe weather and convective parameters (Taszarek et al. 2020). Jointly, the studies enable a better assessment of the threat for convective hazards across Europe and the United States and explain differences between those domains.

\section{Dataset and methodology}

Severe convective storms are studied over 40 years (19792018) over the continental United States and Europe. Lightning and severe weather data are gridded to $0.25^{\circ}$ horizontal spacing and 1-h temporal resolution. This grid spacing is motivated by the resolution of ERA5, which is used with the same observational data in the second part of the study (Taszarek et al. 2020). For statistical analysis we define four subdomains over each continent that present distinct climatological distributions (Fig. 1).

\section{a. United States lightning data}

Lightning-flash counts for the United States were derived from the National Lightning Detection Network (NLDN; 
Sub-domains used in the study

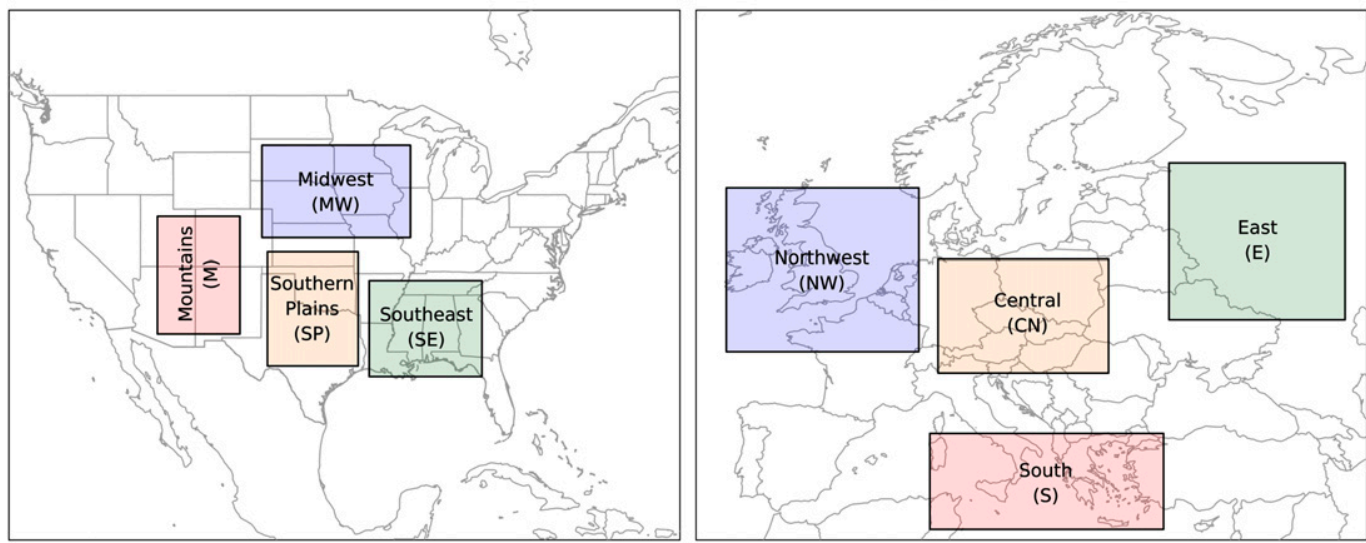

FIG. 1. Definition of regions used in the study. (left) United States: Southeast (SE; $29.25^{\circ}-36.00^{\circ} \mathrm{N}, 83.00^{\circ}-93.25^{\circ} \mathrm{W}$ ), Midwest (MW; $\left.39.00^{\circ}-45.50^{\circ} \mathrm{N}, 89.50^{\circ}-103.00^{\circ} \mathrm{E}\right)$, Southern Plains (SP; $30.00^{\circ}-38.00^{\circ} \mathrm{N}, 94.25^{\circ}-102.50^{\circ} \mathrm{W}$ ), and Mountains (M; $32.25^{\circ}-40.50^{\circ} \mathrm{N}, 105.00^{\circ}-112.50^{\circ} \mathrm{W}$ ). (right) Europe: Northwest (NW; $47.25^{\circ}-58.75^{\circ} \mathrm{N}, 10.25^{\circ} \mathrm{W}-$ $\left.7.25^{\circ} \mathrm{E}\right)$, South $\left(\mathrm{S} ; 34.75^{\circ}-41.50^{\circ} \mathrm{N}, 8.25^{\circ}-29.50^{\circ} \mathrm{E}\right)$, Central $\left(\mathrm{CN} ; 45.75^{\circ}-53.75^{\circ} \mathrm{N}, 9.00^{\circ}-24.50^{\circ} \mathrm{E}\right)$, and East $\left(\mathrm{E} ; 49.50^{\circ}-\right.$ $\left.60.50^{\circ} \mathrm{N} 30.00^{\circ}-46.00^{\circ} \mathrm{E}\right)$.

Fleenor et al. 2009; Cummins and Murphy 2009; Koehler 2020) for 1989-2018, and aggregated to the common grid of $0.25^{\circ}$ at hourly steps. During this time period, NLDN has undergone several upgrades, causing discontinuities. GPS timing data were added in 1995 to the magnetic-field direction-finder stations, while cloud-to-ground (CG) detection efficiency during this time period was between $60 \%$ and $90 \%$ (Cummins et al. 1998). More sensors were installed and upgraded in 2002-03 to improve the CG detection efficiency to $90 \%-95 \%$ (Cummins and Murphy 2009) and again in 2013 to over 95\% (Nag et al. 2014).

Here we use the archive of the quality-controlled NLDN flash data maintained by the National Severe Storms Laboratory. While network detection efficiency undoubtedly results in yearto-year inhomogeneities, the driving motivation here is to explore the largest possible sample size. Furthermore, since metrics used here are thunderstorm hours instead of flash counts, our estimates are less susceptible to spatial and year-to-year variations in the data quality, and by this virtue are more comparable with the European dataset. To ensure consistency with the European dataset, which includes both CG and intracloud (IC) flashes, we do not remove low peak-current discharges, with the understanding that many of them result from IC flashes (Kingfield et al. 2017; Medici et al. 2017). Evaluating the impact of this distinction on our results, the difference in the mean annual number of thunderstorm hours (at least two flashes) for any given location, based on 1) all flashes and 2) flashes with a peak current filter ( $>15 \mathrm{kA})$, extends from around $8 \%$ to $16 \%$ depending on the year.

In total, 868335173 flashes detected over a $30-y r$ period were used in the analysis (Table 1). During 1989-92, the number of detections was lower compared to other years (Fig. 2b), related to lower detection efficiency. Seasonally, the highest number of flashes on average unsurprisingly occurs during summer, followed by spring, autumn, and the winter minima (Fig. 2b).

TABLE 1. Datasets used in the study.

\begin{tabular}{|c|c|c|c|c|c|}
\hline Category & Database & Sample size & Grid/step & Time domain & Additional note \\
\hline Lightning & $\begin{array}{l}\text { United States-NLDN } \\
\text { Europe-ATDnet }^{\mathrm{a}}\end{array}$ & $\begin{array}{l}868335173 \text { flashes } \\
180508624 \text { flashes }\end{array}$ & $\begin{array}{l}0.25^{\circ} / 1 \mathrm{~h} \\
0.25^{\circ} / 1 \mathrm{~h}\end{array}$ & $\begin{array}{l}1989-2018 \\
2006-2018\end{array}$ & $\begin{array}{l}\text { A thunderstorm hour is defined when at } \\
\text { least two flashes per hour per grid are } \\
\text { detected. }\end{array}$ \\
\hline Tornado & $\begin{array}{l}\text { United States-SPC } \\
\text { Europe-ESWD }\end{array}$ & $\begin{array}{l}45062 \text { reports } \\
4876 \text { reports }\end{array}$ & $\begin{array}{l}0.25^{\circ} / 1 \mathrm{~h} \\
0.25^{\circ} / 1 \mathrm{~h}\end{array}$ & $\begin{array}{l}1979-2018 \\
1979-2018\end{array}$ & Waterspouts rated F0 excluded. \\
\hline Large hail & $\begin{array}{l}\text { United States-SPC } \\
\text { Europe-ESWD }\end{array}$ & $\begin{array}{l}239947 \text { reports } \\
13743 \text { reports }\end{array}$ & $\begin{array}{l}0.25^{\circ} / 1 \mathrm{~h} \\
0.25^{\circ} / 1 \mathrm{~h}\end{array}$ & $\begin{array}{l}1979-2018 \\
1979-2018\end{array}$ & $\begin{array}{l}\text { Hailstones with diameter }<2 \mathrm{~cm} \\
\text { excluded. }\end{array}$ \\
\hline Severe wind & $\begin{array}{l}\text { United States-SPC } \\
\text { Europe-ESWD }\end{array}$ & $\begin{array}{l}382252 \text { reports } \\
27115 \text { reports }\end{array}$ & $\begin{array}{l}0.25^{\circ} / 1 \mathrm{~h} \\
0.25^{\circ} / 1 \mathrm{~h}\end{array}$ & $\begin{array}{l}1989-2018 \\
2006-2018\end{array}$ & $\begin{array}{l}\text { Only cases with } 45 \mathrm{~km} \text { spatial and } \pm 1-\mathrm{h} \\
\text { temporal proximity of lightning } \\
\text { were used. }\end{array}$ \\
\hline
\end{tabular}

\footnotetext{
${ }^{a}$ National Lightning Detection Network (Koehler 2020)

${ }^{\mathrm{b}}$ Arrival Time Difference lightning-detection network (Enno et al. 2020)

${ }^{c}$ Storm Prediction Center Severe Weather Database (Schaefer and Edwards 1999)

${ }^{\mathrm{d}}$ European Severe Weather Database (Dotzek et al. 2009)
} 
a

Severe weather reports over the years

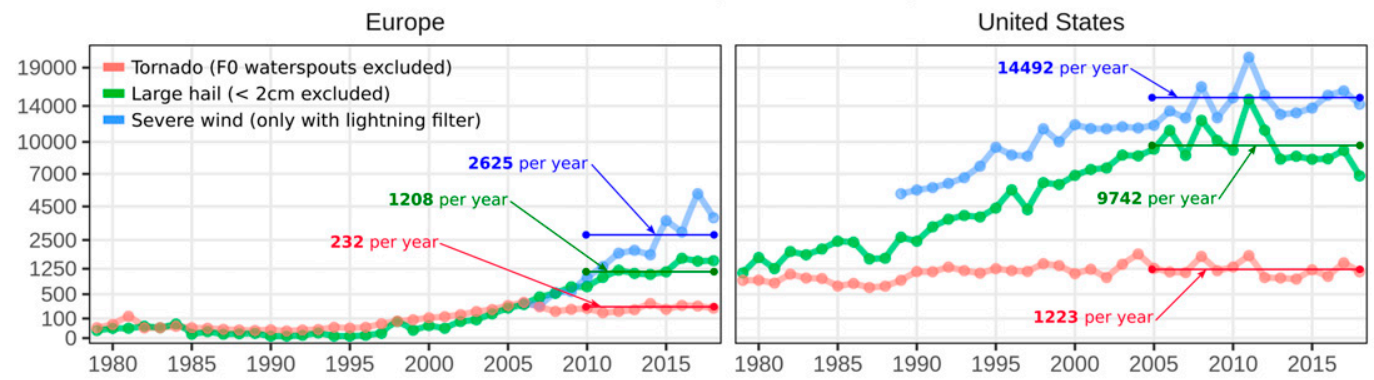

b

Flashes (thousands) over the years
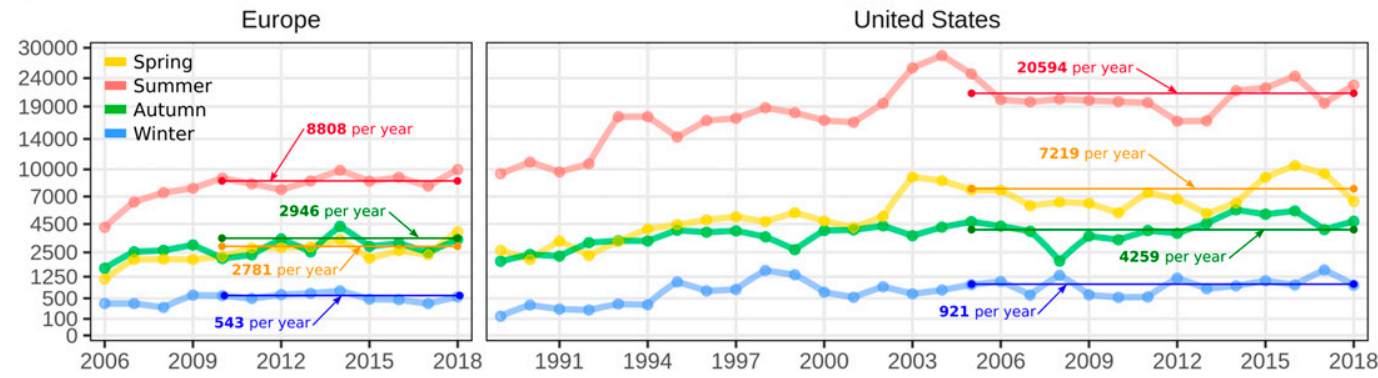

FIG. 2. Frequency of (a) tornado (red), large hail (green), and severe wind (blue) reports, and (b) flashes (thousands) in spring (yellow), summer (red), autumn (green), and winter (blue) for (left) Europe and (right) the United States over the years. Mean values (indicated as horizontal lines) for Europe are derived for years 2010-18 and for $2005-18$ for the United States.Values over the vertical axis are presented in a square root scale.

\section{b. European lightning data}

For Europe, lightning flash counts for the period 2006-18 were used from the Arrival Time Difference lightningdetection network (ATDnet; Anderson and Klugmann 2014; Enno et al. 2020) operated by the Met Office. ATDnet is a very low-frequency (VLF) long-range system that locates lightning discharges using the arrival time difference (ATD) method (Lee 1986). ATDnet sensors detect sferics, which are VLF electromagnetic waves propagating in the Earth-ionosphere waveguide, and can be generated by CG lightning return strokes or high-current cloud-lightning pulses (Rakov and Uman 2003). Sferics can propagate thousands of kilometers, which makes it possible to cover large areas with a limited number of sensors. During the study period, ATDnet consisted of 10 sensors operating at the central frequency of $13.733 \mathrm{kHz}$ (Enno et al. 2020). The effective range of ATDnet encompasses Europe, northern Africa, and part of the northern Atlantic Ocean.

ATDnet is capable of detecting up to $90 \%$ of CG flashes and $25 \%$ of IC flashes during the day (Enno et al. 2016). A lower nighttime detection efficiency has been reported (Poelman et al. 2013a), as ATDnet is tuned for optimal performance under the daytime ionosphere. Evaluating locational accuracy compared to short-range lightning systems, spatial precision of ATDnet is ranging over $1-2 \mathrm{~km}$ over western Europe and around $5-10 \mathrm{~km}$ in the remaining part of the studied domain (Bennett et al. 2010; Poelman et al. 2013a,b).

In total, 180508624 flashes in 13 years were aggregated on the common grid of $0.25^{\circ}$, at hourly steps (Table 1 ). Due to the network upgrade in 2007 (Enno et al. 2020) the number of detections in 2006 was lower compared to other years (Fig. 2b). The annual cycle of flashes is similar to that of the United States, except for less distinction between the fall and spring (Fig. 2b).

\section{c. United States severe weather reports}

Severe weather data in the United States are collected from storm reports submitted by local NWS offices, with local quality-control and removal of duplicate records. Specific reports are also updated with damage-survey data (e.g., tornado ratings). The final quality-controlled dataset consisting of large hail, tornado, and severe wind reports, called Storm Data, is then collated by the Storm Prediction Center (available at www.spc.noaa.gov/wcm; Schaefer and Edwards 1999).

Tornadoes in the United States were rated on the original Fujita (F) scale before February 2007 and on the enhanced Fujita (EF) scale since (Doswell et al. 2009; Edwards et al. 2013). For this paper we consider F-scale ratings to be equivalent to EF-scale ratings. Since the nationwide deployment of the Weather Surveillance Radar-1988 Doppler (WSR-88D; Weber et al. 2007) network and the modernization of the NWS warning and data-gathering practices that occurred in the mid 1990s, around 1200 tornadoes are reported each year on average (Fig. 2a). Increasing photo and video documentation of tornadoes through spotting and storm chasing (Edwards et al. 2013) and improvements in technology have also led to more reports of the weakest (F0) tornadoes over the last few decades. Meanwhile, the frequency of tornadoes rated at least F1 has remained relatively constant (Verbout et al. 2006). Long-term increases in the variability and intensity of tornado 
outbreaks since the 1970s have been described by Brooks et al. (2014), Elsner et al. (2015), and Tippett et al. (2016).

Severe convective winds are recorded when their measured or estimated speed is $\geq 50 \mathrm{kt}\left(25 \mathrm{~m} \mathrm{~s}^{-1}\right)$. However, estimated speeds should be treated with caution, as considerable subjectivity is involved (Doswell et al. 2005; Trapp et al. 2006; Edwards et al. 2018). The ratio of estimated to measured frequency of convective wind reports over the United States is nearly 9:1, and is the highest over the East and the lowest over the Great Plains and Midwest. Estimates are often remotely and arbitrarily assigned after the event, and typically have a high bias (Agdas et al. 2012; Edwards et al. 2018). For consistency with European wind data, a lightning filter is applied to all severe wind reports in SPCSD (Table 1). The annual mean number of wind reports in the United States is 14492 over the period 2005-18 (Fig. 2a).

Large hail events in SPCSD are measured or estimated, but before 2011 they must have had a diameter $\geq 0.75$ in. $(2 \mathrm{~cm}$; Doswell et al. 2005). At the end of 2010, this threshold was increased to $1 \mathrm{in}$. $(2.5 \mathrm{~cm})$, which introduced a discontinuity, despite some portion of 0.75 in. hail still being reported after 2010 (Allen and Tippett 2015). For consistency with ESWD data, we use only hail with a diameter $\geq 2 \mathrm{~cm}$ (Table 1 ). Since 2005, a mean of 9742 such reports have entered SPCSD each year (Fig. 2a). The hail data feature a typical bias toward densely populated areas (Dobur 2005; Cecil 2009), but sometimes even significant events are not reported over urban areas (Blair and Leighton 2012). During the 2011-15 HailSTONE field research campaign, the maximum diameter of around $80 \%$ of hail reports that entered Storm Data was underestimated (especially for supercellular hail), while around $30 \%$ of events were not reported (Blair et al. 2017). Amburn and Wolf (1997) and Blair et al. (2011) also indicated that around $25 \%-30 \%$ of the examined hailstorms from Storm Data did not coincide with radar reflectivity at the time of the report. Reporting efficiency is also typically reduced during nocturnal severe weather events, because of limited visibility and sleeping observers (Ashley et al. 2008; Blair et al. 2017). Due to these limitations, hail data should be used with caution, especially when considering trends of $\geq 5 \mathrm{~cm}$ events (Allen and Tippett 2015). Further reading on the limitations of hail data is available in Marzban and Witt (2001), Ortega et al. (2009), Allen et al. (2017), and Allen et al. (2020).

During 1979-2018, in total 45062 tornadoes, 239947 hail, and 382252 convective wind reports were used in this analysis for the United States domain (Table 1).

\section{d. European severe weather reports}

For Europe, large hail, tornado, and severe wind reports were taken from the ESWD (available at www.eswd.eu; Dotzek et al. 2009). ESWD defines a severe wind gust as requiring measured gusts "to have a speed of at least $25 \mathrm{~m} \mathrm{~s}^{-1}$ or one doing such damage that a wind speed of $25 \mathrm{~m} \mathrm{~s}^{-1}$ or higher is likely to have occurred." This contrasts with the SPCSD, in which around $90 \%$ of reports are estimates (Edwards et al. 2018), as no estimates are used in the ESWD. According to ESWD reporting criteria a tornado is defined as "a vortex extending between a convective cloud and the Earth's surface, in which the wind is strong enough to cause damage to objects." For the majority of large hail events, a peak hailstone diameter is derived from a measurement or an estimate based on a picture. In this study, we considered only hailstones with diameters $\geq 2 \mathrm{~cm}$.

The ESWD is characterized by both spatial and temporal inhomogeneity, with a bias toward western and central Europe (Groenemeijer et al. 2017; Taszarek et al. 2019a). However, in recent years this bias has decreased, with a growing number of reports from southern and eastern Europe (Shikhov and Chernokulsky 2018; Chernokulsky et al. 2020). Since 2010 when the report frequency stabilized, a mean of 232 tornadoes, 1208 large hail, and 2625 severe convective wind reports occur each year (Fig. 2a). However, the frequency of wind reports has consistently increased through the record, in contrast to the relatively stable number of tornado and hail reports.

The ESWD uses a system of quality flags to rate report accuracy. For this study, only reports with a credibility status of $\mathrm{QC0}+$ (plausibility check passed), QC1 (report confirmed), and QC2 (scientific case study), with an accuracy of at least $3 \mathrm{~h}$, were included in the analysis. Since the ESWD also contains severe nonconvective wind reports, all events were crossreferenced with lightning data from the ATDnet (Table 1). If no lightning was detected within $45 \mathrm{~km}$ or $\pm 1 \mathrm{~h}$ of the reporting time, the report was considered to be nonconvective and thus excluded. Since lightning data are only available from 2006 onward, severe wind reports before 2006 were not included.

Tornadoes in ESWD are rated using the F scale (Fujita 1971), taking into account the guidelines by Feuerstein et al. (2011). For consistency with the SPCSD, where tornadoes occurring purely over water surface (waterspouts) are not reported, all such cases were also removed from the European dataset. However, waterspouts making landfall, rated at least F1, were retained. Such tornadoes can have significant societal impacts, particularly along the densely populated Mediterranean coasts (Sioutas 2011; Kahraman and Markowski 2014; Miglietta and Rotunno 2016; Renko et al. 2016; Matsangouras et al. 2016, 2017; Miglietta et al. 2017; Rodríguez and Bech 2018, 2020). In total, 4876 tornadoes, 13743 large hail, and 27115 severe wind reports from ESWD were included (Table 1).

\section{e. Smoothing techniques}

To reduce the spatiotemporal limitations in convective reports, smoothing was necessary. Following Taszarek et al. (2019a), annual and diurnal cycles presented in this study are smoothed by applying 30-day and 3-h moving windows, respectively. The peak day of the year (DOY) and hour of the day (HOD) for a specific convective phenomenon are determined using a running mean. For spatial analyses we apply $3 \times 3$ or $5 \times 5$ grid moving windows. In estimates of DOY and HOD we use circular statistics (Pewsey et al. 2013) that allow a continuous transition between 31 December and 1 January, and between 2300 and 0000 UTC, respectively. Duplicated records on the aggregate grid were not taken into account in deriving these estimates.

\section{f. Limitations}

The main limitations arise from inhomogeneities of the observational datasets, although this is offset by the large sample size considered. The ESWD dataset is approximately 
Annual mean number of hours with lightning, tornado, large hail and severe wind $\left(0.25^{\circ}\right.$ grid, based on years $\left.2006-2018\right)$
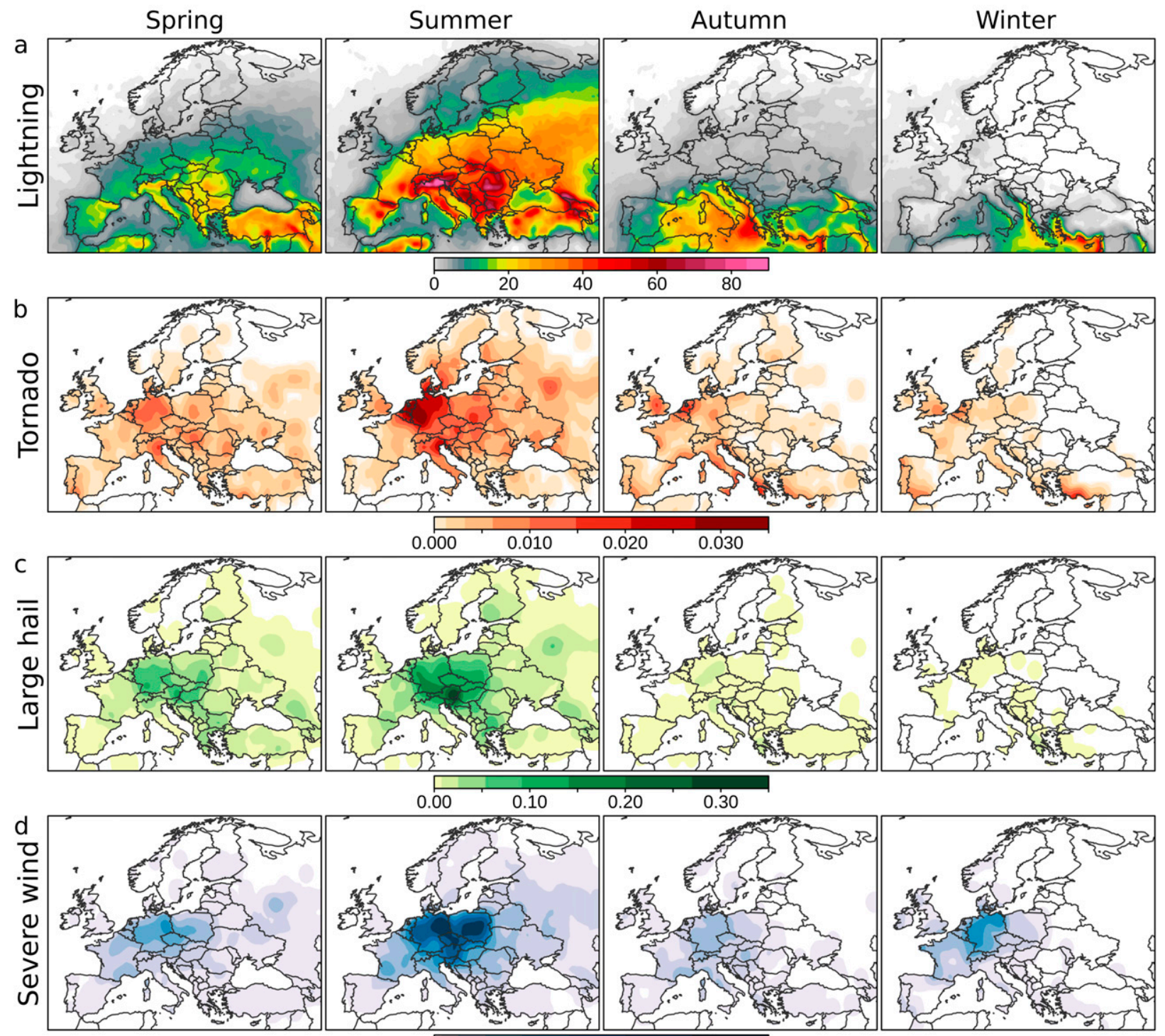

$0.00 \quad 0.10 \quad 0.20$

0.30
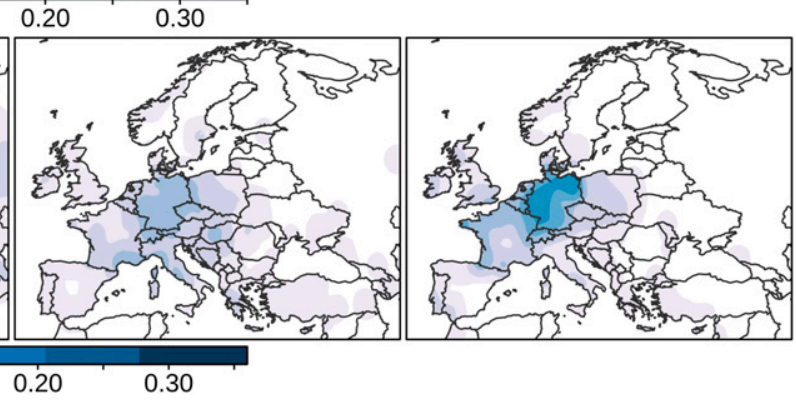

FIG. 3. Annual mean number of hours with (a) lightning, (b) tornadoes, (c) large hail, and (d) severe wind within $0.25^{\circ}$ boxes with a $1.25^{\circ} \times$ $1.25^{\circ}$ spatial smoother over Europe for years 2006-18. Duplicated records (more than one report of the same type occurring in the same box and date) were not taken into account.

15 times smaller than SPCSD and features stronger biases (section 2d). Although SPCSD is larger, it is also not free of biases (section 2c). The relationship of population density to report density and building-construction practices can also influence recording of damage, especially for tornadoes (Edwards et al. 2013; Potvin et al. 2019). The consistently increasing number of severe weather reports over the recent years may also have a statistical effect on DOY and HOD estimates, as more weight is placed on data from recent years compared to the early record.
The difference in the way lightning is detected by the ATDnet and NLDN networks (sections $2 \mathrm{a}$ and $2 \mathrm{~b}$ ) may also introduce small differences when comparing climatological aspects of thunderstorms between Europe and the United States. This also extends to year-to-year and spatial changes in detection efficiency. Although these issues imply some results must be interpreted with some caution, we believe that the majority of biases are mitigated by the large size of the dataset, careful selection of temporal window, and smoothing into climatological frequency. 


\section{Annual mean number of hours with lightning, tornado, large hail and severe wind} $\left(0.25^{\circ}\right.$ grid, based on years $\left.1989-2018\right)$
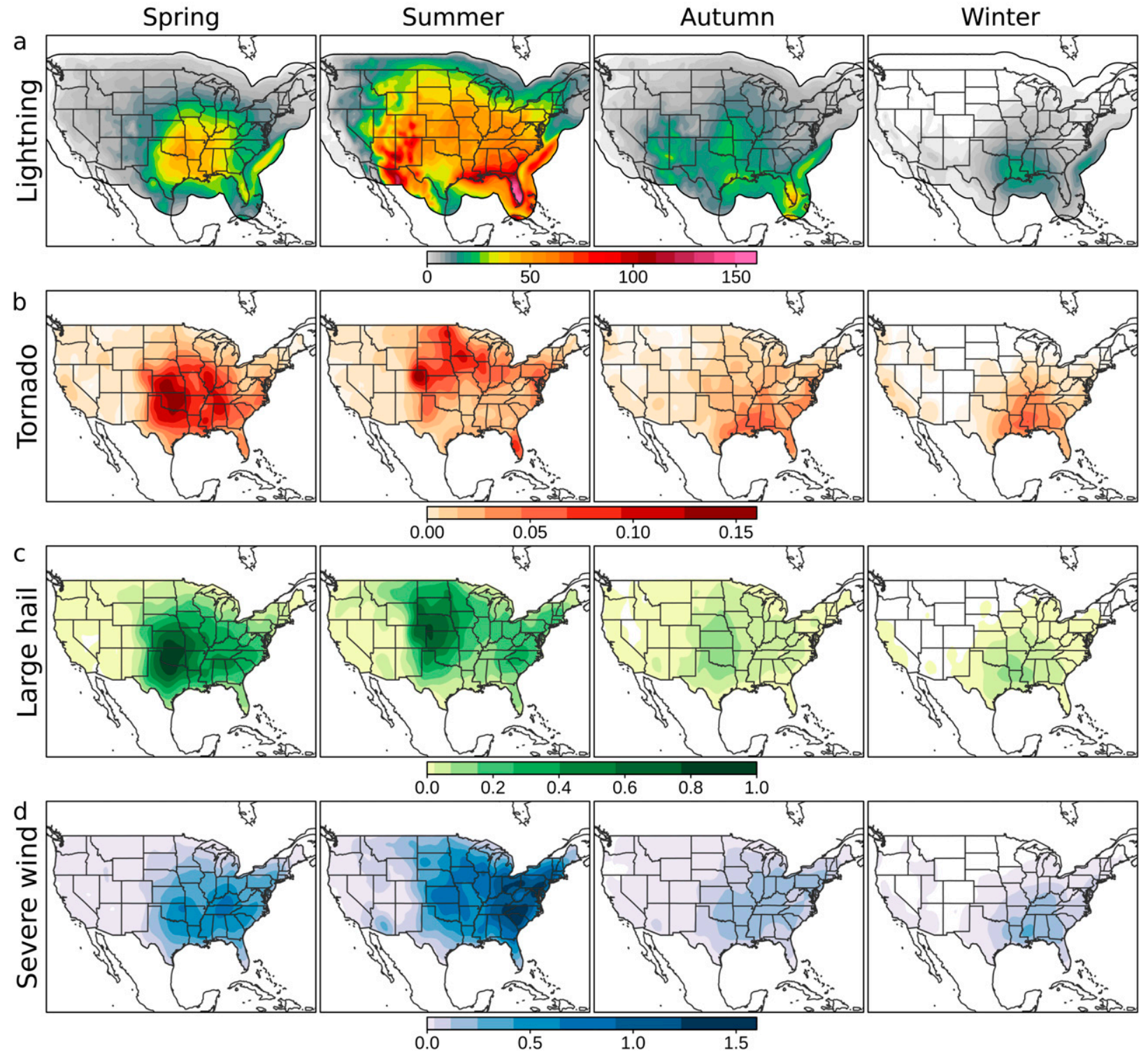

FIG. 4. Annual mean number of hours with (a) lightning, (b) tornadoes, (c) large hail, and (d) severe wind within $0.25^{\circ}$ boxes with a $1.25^{\circ}$ $\times 1.25^{\circ}$ spatial smoother over the United States for years 1989-2018. Duplicated records (more than one report of the same type occurring in the same box and date) were not taken into account.

\section{Results}

\section{a. Spatial variability}

The spatial distribution of annual mean number of hours with lightning over Europe indicates a peak activity during summer with $30-40 \mathrm{~h}$ in a corridor from the northeastern Iberian Peninsula, through central Europe and the Balkans, and into western Russia (Fig. 3a). Local peaks of lightning frequency exceeding 60 thunderstorm hours are observed over mountain ranges such as the Alps, Carpathians, and Dinaric
Alps. During autumn, the convective activity (around $20 \mathrm{~h}$ with thunderstorms per year) shifts toward southern Europe and the warm waters of the Mediterranean Sea. In winter, storms occur mainly over the eastern Mediterranean but occasionally over western portions of Europe as well, typically linked to extratropical cyclones (van Delden 2001; Kolendowicz 2012; Wapler and James 2015; Piper et al. 2019). During spring, intensifying boundary layer warming aids thunderstorm formation over the majority of continental Europe with peaks over Italy, the Balkan Peninsula, and Turkey. 
TABLE 2. Day of year and time of the day with peak probability for convective events over selected regions (Fig. 1).

\begin{tabular}{|c|c|c|c|c|c|c|c|c|}
\hline \multirow[b]{2}{*}{ Region } & \multicolumn{2}{|c|}{ Lightning } & \multicolumn{2}{|c|}{ Tornado } & \multicolumn{2}{|c|}{ Large hail } & \multicolumn{2}{|c|}{ Severe wind } \\
\hline & Day & Hour & Day & Hour & Day & Hour & Day & Hour \\
\hline \multicolumn{9}{|c|}{ United States } \\
\hline Southern Plains (SP) & 4 Jun & $1900 \mathrm{CST}$ & 13 May & $1800 \mathrm{CST}$ & 12 May & $1900 \mathrm{CST}$ & 4 Jun & $1900 \mathrm{CST}$ \\
\hline Midwest (MW) & 29 Jun & $2300 \mathrm{CST}$ & 9 Jun & $1800 \mathrm{CST}$ & 9 Jun & $1900 \mathrm{CST}$ & 30 Jun & $2000 \mathrm{CST}$ \\
\hline Southeast (SE) & $16 \mathrm{Jul}$ & $1600 \mathrm{CST}$ & 17 Apr & $1700 \mathrm{CST}$ & 16 Apr & $1700 \mathrm{CST}$ & 27 Jun & $1700 \mathrm{CST}$ \\
\hline Mountains (M) & 3 Aug & $1700 \mathrm{CST}$ & 4 Aug & $1600 \mathrm{CST}$ & $2 \mathrm{Jul}$ & $1700 \mathrm{CST}$ & 1 Aug & $1900 \mathrm{CST}$ \\
\hline \multicolumn{9}{|c|}{ Europe } \\
\hline Northwest (NW) & $12 \mathrm{Jul}$ & 1600 UTC & 2 Aug & $1600 \mathrm{UTC}$ & 15 Jun & $1700 \mathrm{UTC}$ & $14 \mathrm{Jul}$ & $1600 \mathrm{UTC}$ \\
\hline Central $(\mathrm{CN})$ & $5 \mathrm{Jul}$ & 1600 UTC & 27 Jun & 1600 UTC & 26 Jun & 1600 UTC & $13 \mathrm{Jul}$ & $1700 \mathrm{UTC}$ \\
\hline South (S) & 23 Oct & 1500 UTC & $4 \mathrm{Nov}$ & $1300 \mathrm{UTC}$ & 3 Jun & 1500 UTC & 24 Oct & 1500 UTC \\
\hline East (E) & $7 \mathrm{Jul}$ & 1400 UTC & $25 \mathrm{Jun}$ & $1500 \mathrm{UTC}$ & $10 \mathrm{Jun}$ & $1400 \mathrm{UTC}$ & 17 Jun & $1500 \mathrm{UTC}$ \\
\hline
\end{tabular}

Severe weather reports follow a similar annual cycle with the highest frequency during summer; however, they are biased toward central Europe. The peak density of tornado reports coincides with the high population density over Belgium, the Netherlands, and northern Germany (Fig. 3b). Large hail frequency peaks over portions of central Europe, especially the eastern Alps (Fig. 3c). Severe wind, which is the dominant hazard in each season, has the most reports over Germany, Poland, the Czech Republic, and Austria where reporting efficiency is the highest (Fig. 3d). During winter, severe weather reports are mainly limited to western Europe and portions of Italy, Greece, and Turkey, which is consistent with the distribution of lightning frequency.

Compared to Europe, thunderstorms are twice as frequent over the United States, with as many as 4 times more storm reports. Lightning frequency is the highest during summer over the central and eastern part of the country east of the Rocky Mountains (60-80 thunderstorm hours) with a local peak over Florida (100-150 thunderstorm hours; Fig. 4a). Tornadoes and hail are more common during spring over the southern Great Plains when lightning occurrence is high, but still below the annual lightning maximum in summer. This implies that springtime thunderstorms in the United States have a high conditional probability of severe weather. During summer, the highest frequency of large hail and tornadoes shifts to the northern portions of the Great Plains and the Midwest. Wind events have different spatial patterns and are reported most often during spring and summer over the more densely populated eastern United States (Fig. 4d). During autumn and winter, lightning activity decreases and shifts with the tornado and wind threat to the southeastern United States, which can experience storm activity all year round.

\section{b. Annual variability}

Over the southeast United States, the large hail threat peaks in mid-April, and then decreases during the remainder of the year (Table 2; Figs. 5c and 6b). Maxima shift with westward and northward extent, with an early May maximum over the southern Great Plains, early June in the Midwest, and late June over the Rocky Mountains. The tornado threat is similar to large hail, with the exception of the Southeast, where a bimodal distribution can be observed, featuring a secondary smaller peak during late autumn and winter (Fig. 6d). Severe wind reports, in contrast, are similar to lightning, having maxima in June and July across most of the country, coinciding with the climatology of mesoscale convective systems (MCSs; Haberlie and Ashley 2018, 2019). A notable exception is Texas and Louisiana, which peak in May (Fig. 5d). Over the southwest the North American monsoon (Adam and Comrie 1997) induces the most frequent thunderstorms during August and September.

Thanks to a diversified coastline, complex orography, and a strong influence of extratropical cyclones (Kolendowicz 2012; Piper et al. 2019) and blocking patterns (Mohr et al. 2019, 2020), Europe has a strongly varying annual pattern of convective hazards. The peak probability for European lightning occurs in late May over the Iberian Peninsula and Turkey, in July within a corridor from the British Isles to western Russia, and in August over northern Europe (Table 2, Figs. 5a and 6a). Over the warmer waters of the east Atlantic and Mediterranean, the persistently warm surface temperatures lead to a maximum during the late autumn and winter. Contrasting the spring peak over the United States, large hail across most of Europe is the most frequent in June and July, with the exception of southern Italy and Greece, where the maximum occurs in winter. The severe wind and tornado occurrences have similar annual cycle patterns over central and eastern Europe (Figs. 5b,d and 6c,d). The tornado and severe wind threat over the Mediterranean basin resemble the lightning distribution with a maximum in autumn, in agreement with Groenemeijer and Kühne (2014). Tornadoes over northwestern Europe, and particularly the British Isles, are the most frequent during late summer, typically from linear systems (Mulder and Schultz 2015; Apsley et al. 2016). Northwestern Europe has also a clear bimodal distribution of severe winds associated with summertime convection and wintertime cyclones (Figs. 5d and 6c).

\section{c. Diurnal variability}

Diurnal variability has greater regional consistency compared to the annual cycles. The strong correlation of diurnal heating with convective activity implies that the peak probability for severe thunderstorms occurs in the late afternoon. Tornado and large hail threats peak around 1600-1700 CST in the eastern United States (1500-1600 CST over Florida) and later (1800-1900 CST) across the Great Plains (Table 2; 
Day of the year with peak probability for lightning, tornado, large hail and severe wind (30-day running window, based on years 1989-2018 for USA and 2006-2018 for EU)

a

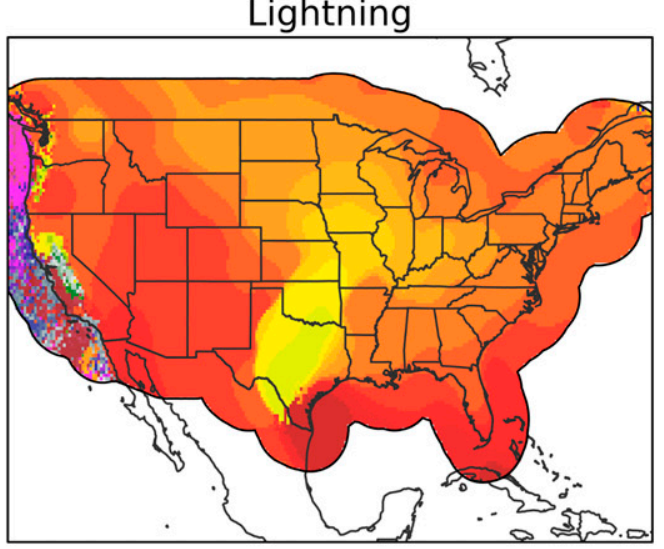

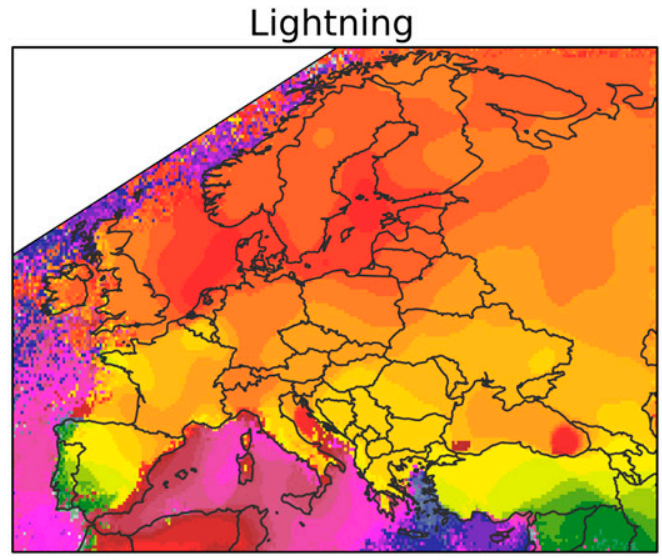

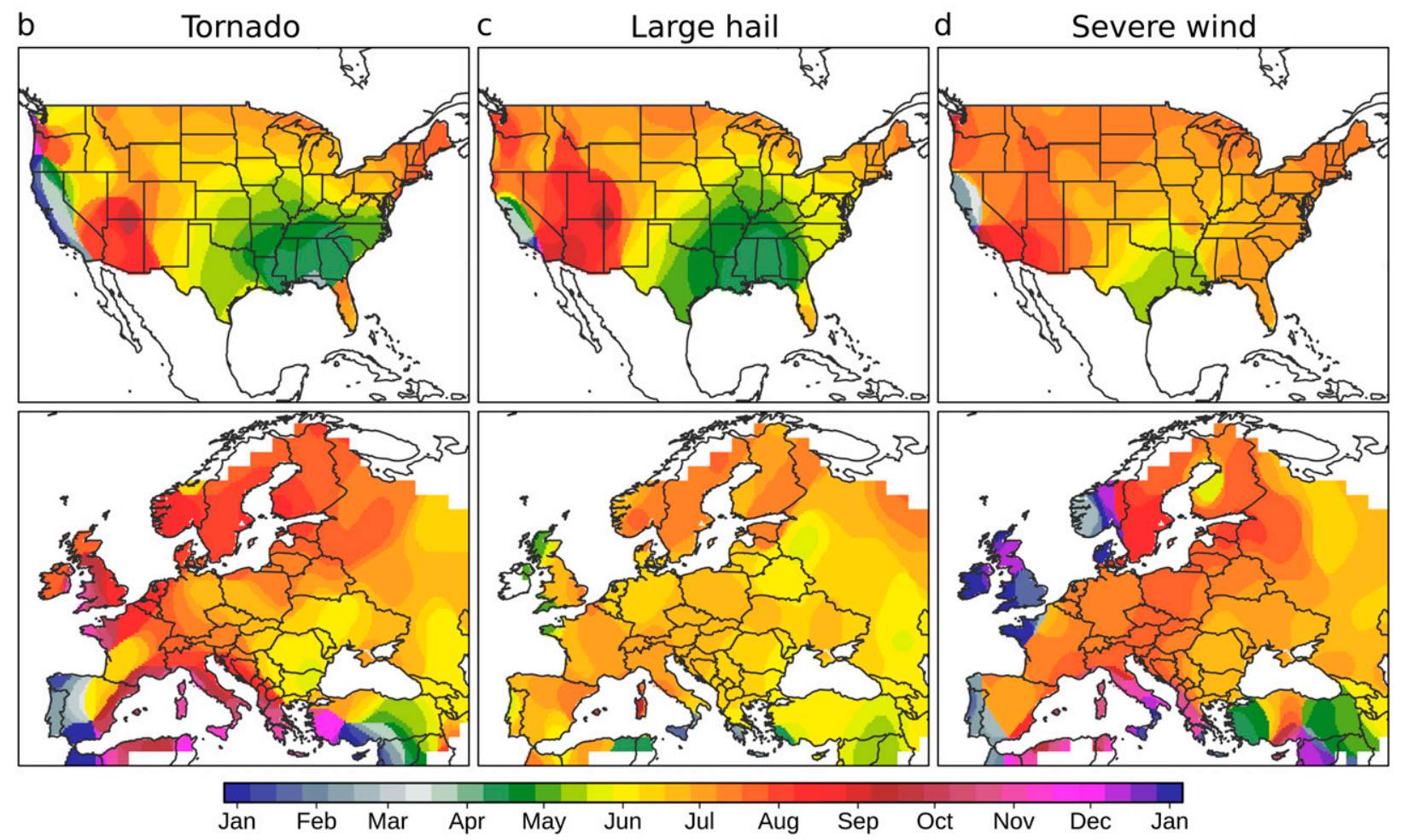

FIG. 5. Day of the year with peak probability for (a) lightning, (b) tornados, (c) large hail, and (d) severe wind over the United States (1989-2018) and Europe (2006-18), derived from a 30-day running window over hourly resolution. Data are presented in $0.25^{\circ}$ boxes with $1.25^{\circ} \times 1.25^{\circ}$ spatial smoother based on circular statistics. Duplicated records (more than one report of the same type occurring in the same box and date) were not taken into account.

Figs. $7 \mathrm{~b}, \mathrm{c}$ and $8 \mathrm{~b}, \mathrm{~d})$. The Southeast has the highest fraction of nighttime tornadoes compared to other areas, although it still maintains a late afternoon peak (Fig. 8d). These results are broadly consistent with Krocak and Brooks (2018). Compared to large hail and tornadoes, the peak for severe wind has a lag of approximately $1 \mathrm{~h}$ (Table 2; Fig. 7d). Lightning probabilities typically follow the patterns in severe weather reports with the exception of the Great Plains and the Midwest, where the highest fraction occurs during night (2200-0400 CST; Fig. 7a). This is best explained by the frequent occurrence of MCSs that under the support of a low-level jet persist through the night and, occasionally, early morning (Shapiro et al. 2016; Geerts et al. 2017; Reif and Bluestein 2017; Haberlie and Ashley 2018, 2019). Conversely, western mountain convection initiates 
Fractional annual variability of convective events*
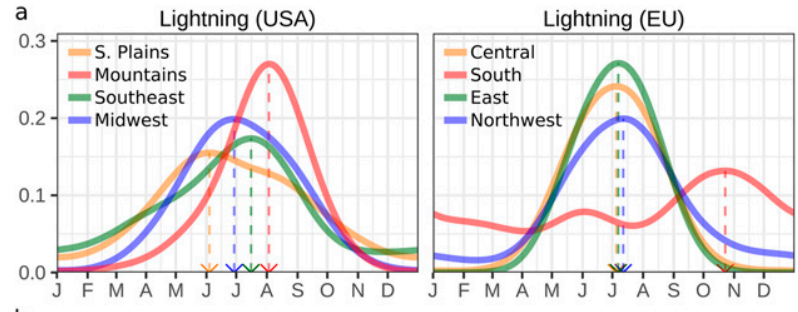

b
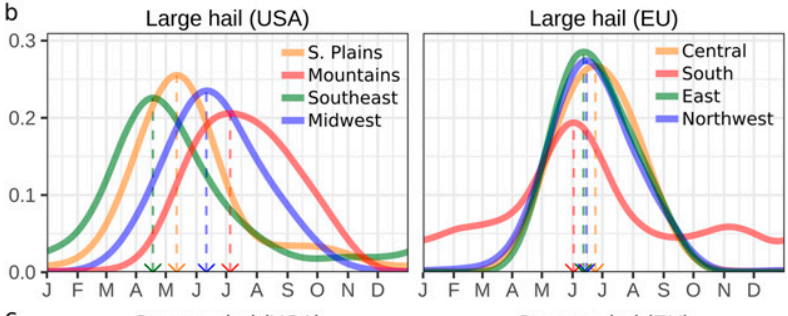

C
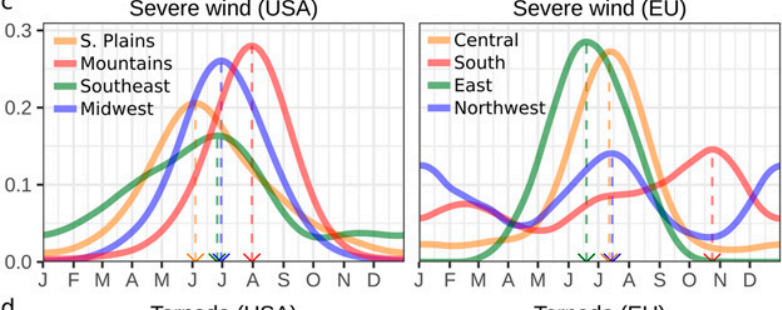

d Tornado (USA)

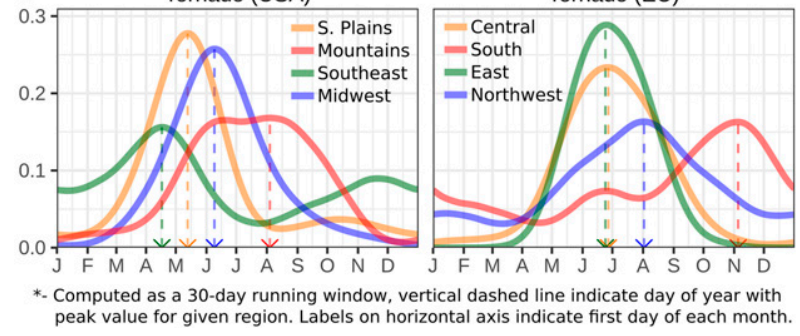

FIG. 6. Fractional annual variability of (a) lightning, (b) large hail, (c) severe wind, and (d) tornadoes over (left) the United States (red-Mountains, blue-Midwest, orange-southern Great Plains, greenSoutheast) and (right) Europe (red-South, blue-Northwest, orangeCentral, green-East), derived from a 30-day running window. Regions are defined in Fig. 1. Duplicated records (more than one report of the same type occurring in the same box and date) were not taken into account. Vertical dashed lines indicate day of year with peak value for a given region.

earlier, with a well-defined peak around 1700 CST and little nocturnal lightning activity (Fig. 8a). Convection over warm waters of the Gulf of Mexico is the most frequent in the morning (0800-1200 CST), and over Gulf Stream during the night (0000-0600 CST; Fig. 7a).

Over Europe, the peak in lightning activity shifts from around 1300-1400 UTC over eastern and southeastern Europe to 1500-1600 UTC over central, southern, and western Europe, and to 1700-1800 UTC over the Southwest (Table 2; Figs. 7a and 8 a). Similar patterns appear for large hail, severe wind, and tornado data, but with a lag of $1-2 \mathrm{~h}$. Over the south and southeast of Europe, tornadoes peak diurnally earlier, around 1100-1300 UTC. Southern Europe also has the highest fraction of nocturnal tornadoes (Fig. 8d). MCSs most commonly occur over Europe during summer (Morel and Sensei 2002; Punkka and Bister 2015; Surowiecki and Taszarek 2020). However, this does not correspond to a nocturnal lightning peak (similar to the Great Plains), suggesting a stronger relationship to diabatic heating. The highest fraction of nocturnal activity is observed over the Mediterranean basin, where storms are the most likely to occur between 2300 and 0500 UTC (Fig. 7a).

\section{d. Other characteristics of lightning data}

Annual mean lightning statistics over Europe show that the lowest overall storm activity is observed over Scandinavia, British Isles, and northern Atlantic (below 25 thunderstorm hours per year), while the highest exceeds $100 \mathrm{~h}$ over Italy, the Balkan Peninsula, and mountain ranges (Fig. 9a). The central and eastern United States generally experience more than $75 \mathrm{~h}$ with a thunderstorm per year. The highest values are found over Florida, reaching 200-250 h. However, these storms are almost exclusively tied to diabatic heating with the fraction of nocturnal lightning below 10\% (Fig. 9b). Fractions exceeding $50 \%$ encompass the northern Great Plains related to nocturnal MCS activity, a pattern not seen over Europe. The remaining part of the country has fractions ranging from $20 \%$ to $30 \%$, which is similar to the continental Europe. The highest fraction of European nocturnal lightning is over eastern Mediterranean (60\%$80 \%$ ) and the lowest (below $10 \%$ ) over Spain, central Italy, the Balkan Peninsula, and Turkey (Fig. 9b).

Mean number of hours with lightning per thunderstorm day (Fig. 9c) indicate that storms over the central United States (Oklahoma, Kansas, Missouri) and along European mountain ranges (Pyrenees, Alps, Carpathians, Dinaric Alps) usually have the longest duration, or are associated with repeated convective events. This parameter ranges from 1.25 within areas where thunderstorms are rare (Scandinavia, British Isles) up to $3 \mathrm{~h}$ over regions with frequent MCS occurrences (e.g., eastern Kansas; Fig. 9c). The mean number of flashes per thunderstorm hour is approximately twice as high over the United States compared to Europe (Fig. 9d), reflecting stronger buoyancy (further explored in the second part of the study; Taszarek et al. 2020). Storms with the highest mean flash rates are the most frequent over southern Great Plains, Florida, and portions of the Midwest. Although storms developing under the North American monsoon over southwest are relatively frequent (100-150 h with thunderstorms per year), they produce very low flash rates (a mean of 10-18 $\mathrm{h}^{-} 1$; Fig. 9d). Over Europe, a spatial distribution of thunderstorm frequency is inconsistent with mean flash rates. Although thunderstorms over Italy are more common, similar flash rates can be observed over France, Germany, or Poland, even though storms are less frequent. However, these patterns may be driven by the spatially varying lightning-detection efficiency of ATDnet and NLDN networks, and thus should be interpreted with caution.

Combining lightning with severe weather reports allows assessment of the percentage of lightning hours associated with convective hazards. This parameter is strongly biased toward more densely populated areas, especially considering large 
Hour* of the day with peak probability for lightning, tornado, large hail and severe wind (3-hour running window, based on years 1989-2018 for USA and 2006-2018 for EU)

a

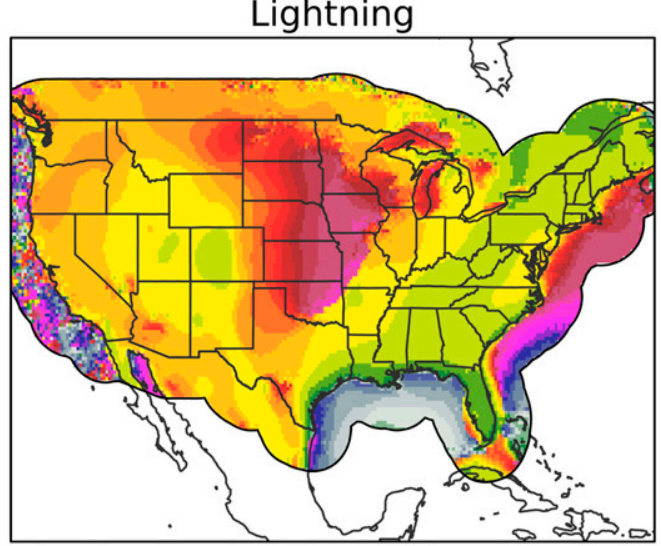

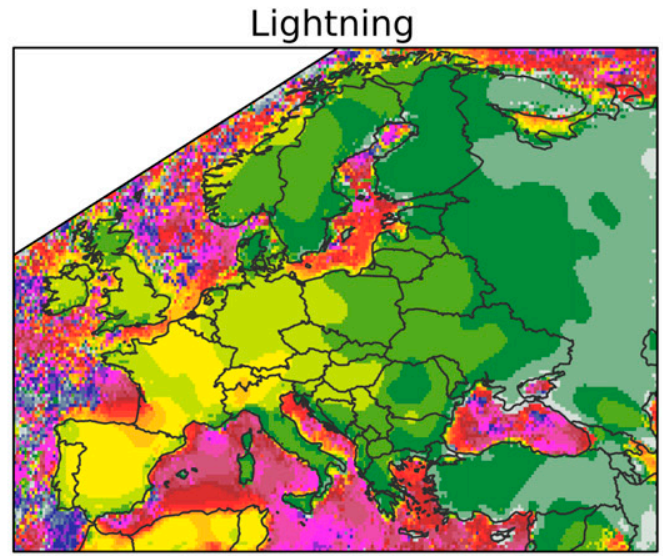

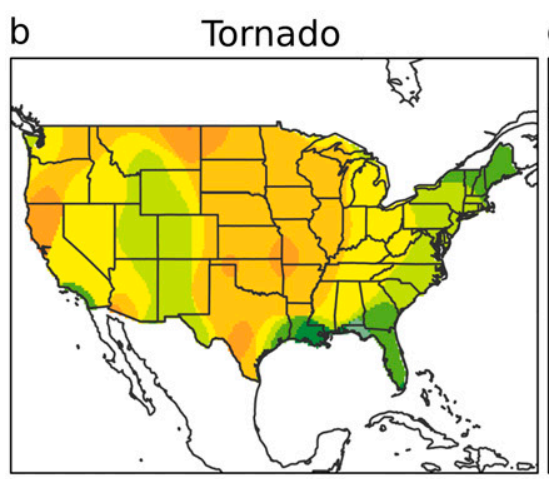

c Large hail

d Severe wind

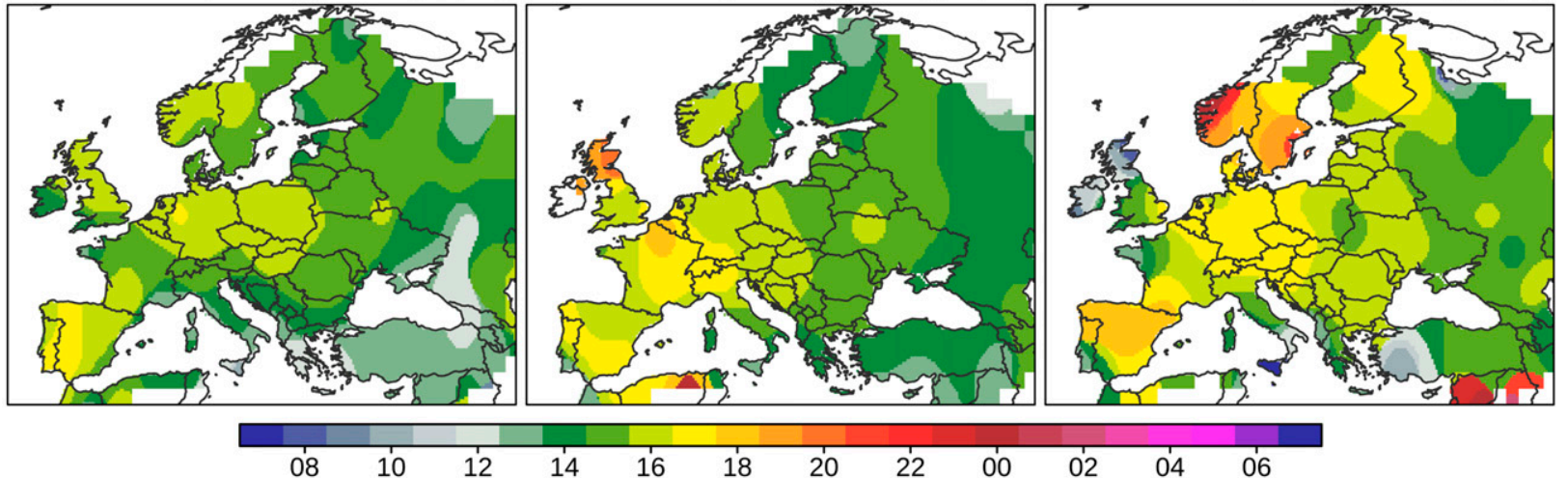

* - UTC time for Europe and CST for the United States

FIG. 7. Hour of the day with peak probability for (a) lightning, (b) tornadoes, (c) large hail, and (d) severe wind over the United States (1989-2018) and Europe (2006-18), derived from a 3-h running window (UTC for Europe and CST for the United States). Data are presented in $0.25^{\circ}$ boxes with a $1.25^{\circ} \times 1.25^{\circ}$ spatial smoother based on circular statistics. Duplicated records (more than one report of the same type occurring in the same box and date) were not taken into account.

metropolitan areas (Fig. 10a). The majority of the United States east of the Rockies has severe weather fractions exceeding $1 \%-2 \%$, with tornadoes only occupying a tenth of the time compared to large and severe wind reports. Peak fractions for tornadoes and large hail are observed over the Great Plains, including sparsely populated western Kansas, with $0.3 \%$ and $3 \%$ for tornadoes and large hail respectively
(Figs. 10b,c). Severe wind reports are again distinct from other hazards, with the highest fraction $(4 \%-5 \%)$ concentrating in densely populated areas over east and northeastern United States, consistent with geographic biases for estimated convective wind in Edwards et al. (2018).

In Europe, the fraction of severe weather reports ranges from $1 \%$ to $5 \%$ over areas with high reporting efficiency 
Fractional diurnal variability of convective events*

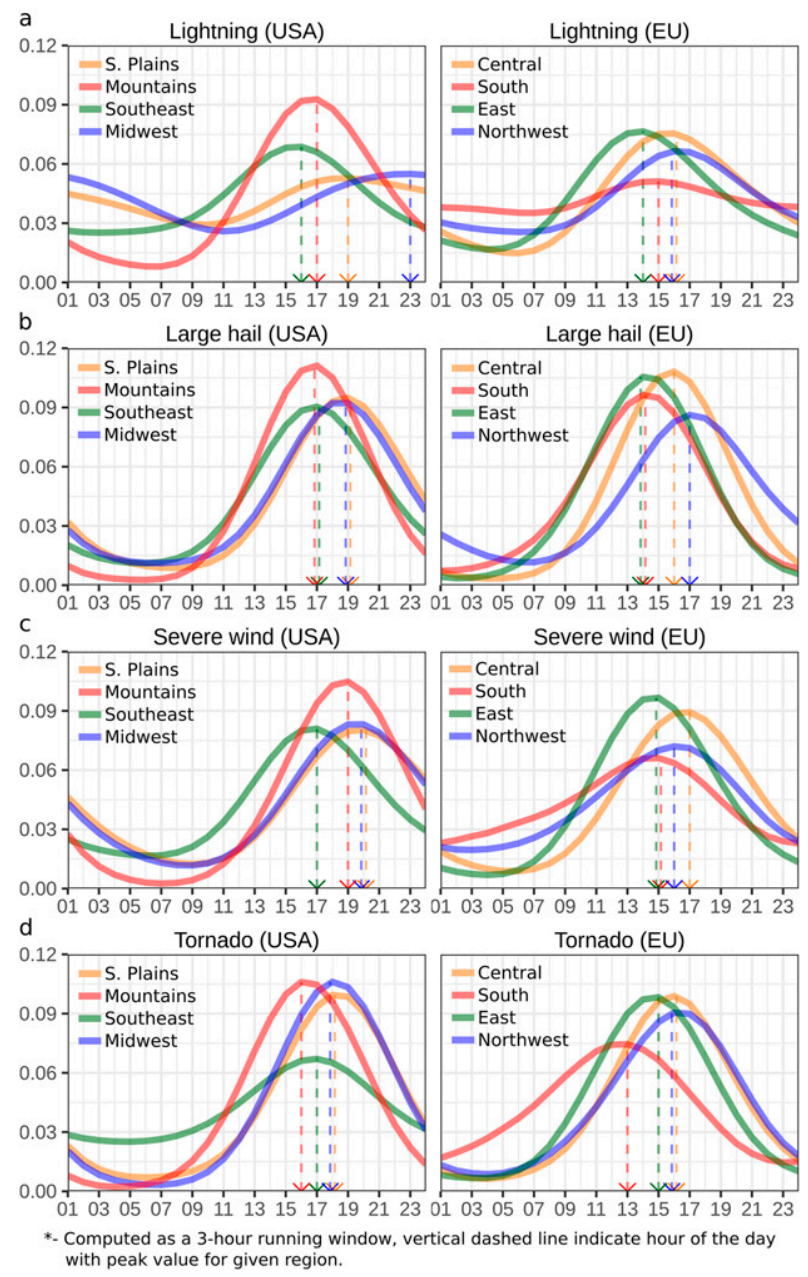

FIG. 8. Fractional diurnal variability of (a) lightning, (b) large hail, (c) severe wind, and (d) tornadoes over (left) the United States and (right) Europe. Colors as in Fig. 6. Derived from a 3-h running window (UTC for Europe and CST for the United States). Regions are defined in Fig. 1. Duplicated records (more than one report of the same type occurring in the same box and date) were not taken into account. Vertical dashed lines indicate the hour of the day with peak value for a given region.

(Belgium, Netherlands, Germany, the Czech Republic, Austria, Poland; Fig. 10a). Outside this area, a notable drop in these fractions can be observed, which suggests underreporting in the ESWD (e.g., the clear cutoff along the border of Poland and Ukraine). Surprisingly, for tornado reports, the peak fraction over the densely populated Belgium and Netherlands (only $25 \mathrm{~h}$ with thunderstorms per year) matches tornado fractions over Kansas (Fig. 10b). However, tornadoes over this region are typically weak and short-lived (Antonescu et al. 2016) in contrast to stronger supercell tornadoes over Kansas (Smith et al. 2012). Fractional occurrences peak for hailstorms over Germany and Austria (around 1\%) but are still notably lower than across the Great Plains (2\%-3\%; Fig. 10c). For severe winds, the fractions of convective hazards over Poland, Germany, and the
Czech Republic are more similar to the United States (1\%-2\%; Fig. 10d). However, peak values observed in Berlin (3\%) are still lower than the northeastern United States (e.g., Boston, Massachusetts; 5\%).

Annual variability of these fractions also offer interesting insights (Fig. 11). Over the United States, and specifically the Great Plains, the fraction of storms with severe weather is highest during spring $(5 \%-7 \%)$. This signature subsequently decreases over the summer $(3 \%-5 \%)$ and autumn $(1 \%-2 \%)$ to increase again to $6 \%-8 \%$ over the southeastern United States during winter. Over Europe, the fraction of severe storms ranges between $1 \%$ and $3 \%$ over central Europe during the spring and summer, and increases to $3 \%-4 \%$ in autumn and $8 \%-12 \%$ during winter (Fig. 11d). The frequency of thunderstorms over Europe significantly drops in winter, but due to climatologically strong vertical wind shear during that period (Taszarek et al. 2020), any convection that develops has an enhanced potential of producing severe wind. These systems are usually associated with (deep) extratropical cyclones and narrow-cold-frontal rainbands (Gatzen 2011; Surowiecki and Taszarek 2020). A similar pattern during wintertime storms is also observed over the United States.

\section{e. Extreme convective events}

The regional frequency of high-end events may not necessarily follow the same spatial and temporal patterns as lightning climatologies (e.g., Florida). Here we divide each phenomenon into three intensity categories and display their contribution to frequency for various regions (Fig. 12). Lightning events are divided into low, medium, and high activity, based on whether $1-25,25-100$, or more than 100 flashes were detected per hour and grid cell, respectively. Over Europe, the highest share of medium $(9.5 \%)$ and high $(1.8 \%)$ categories was found over central Europe, while for other regions medium and high have $6 \%$ and $1 \%$, respectively (Fig. $12 \mathrm{a}$ ). Over the United States only the mountainous areas have percentages similar to Europe. Across the southern Great Plains, Midwest, and Southeast, medium activity typically has a share of $13 \%$ and high activity between $3.5 \%$ and $4.5 \%$ (which is almost 4 times higher than Europe), reflecting greater availability of instability.

Among tornadoes, $80 \%-90 \%$ of all tornado cases are weak, F0-F1 (Fig. 12b). Strong F2-F3 events comprise 7.8\% and 21\% over southern and central Europe, respectively. Interestingly, this exceeds the highest fraction across the United States, where the share of strong tornadoes is $18 \%$. Two potential explanations for this signal may be the underreporting of weaker tornadoes in Europe as compared to the United States, or potentially the higher likelihood of damage in densely populated Europe. Over the southern Great Plains and the Midwest, strong tornadoes consist of $11.6 \%$ and $13.1 \%$ respectively, which is similar to the $15 \%$ fraction over eastern Europe (Fig. 12b). Violent tornadoes (F4-F5) are very rare events $(\sim 0.1 \%)$ with few cases reported over Europe in the entire 40-yr period. Over the United States, that frequency is higher and ranges from $0.8 \%$ in the Midwest to $1.1 \%$ across the Southeast.

Reported hail diameters are divided into three categories, $2-5 \mathrm{~cm}$ (large), $5-8 \mathrm{~cm}$ (very large), and $\geq 8 \mathrm{~cm}$ (giant; Fig. 12c). 


\section{Selected characteristics of lightning data}

a

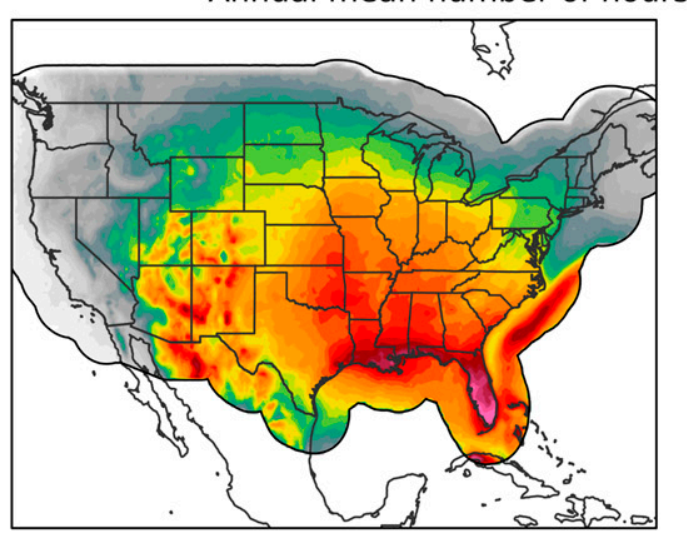

50

b Fraction of nocturnal lightning (sun angle $<0^{\circ}$ )

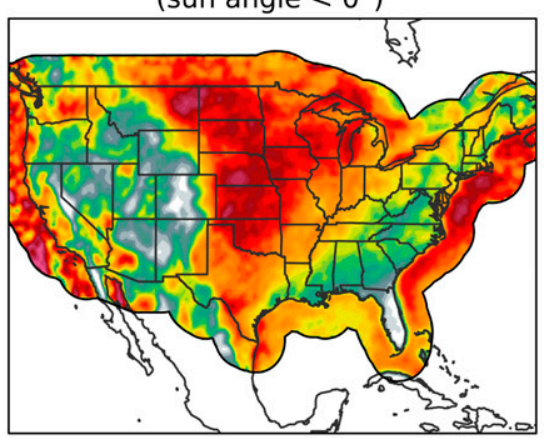

C Mean number of hours with lightning per thunderstorm day

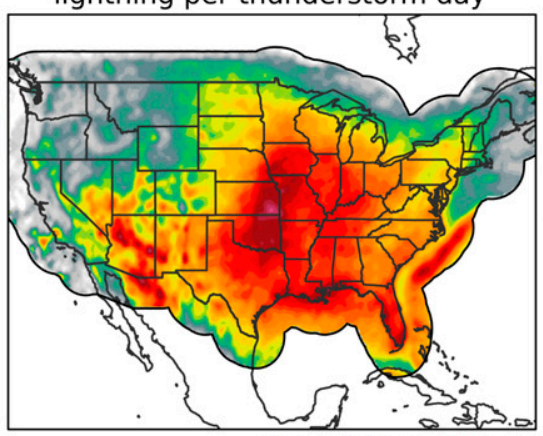

d Mean number of flashes per thunderstorm hour
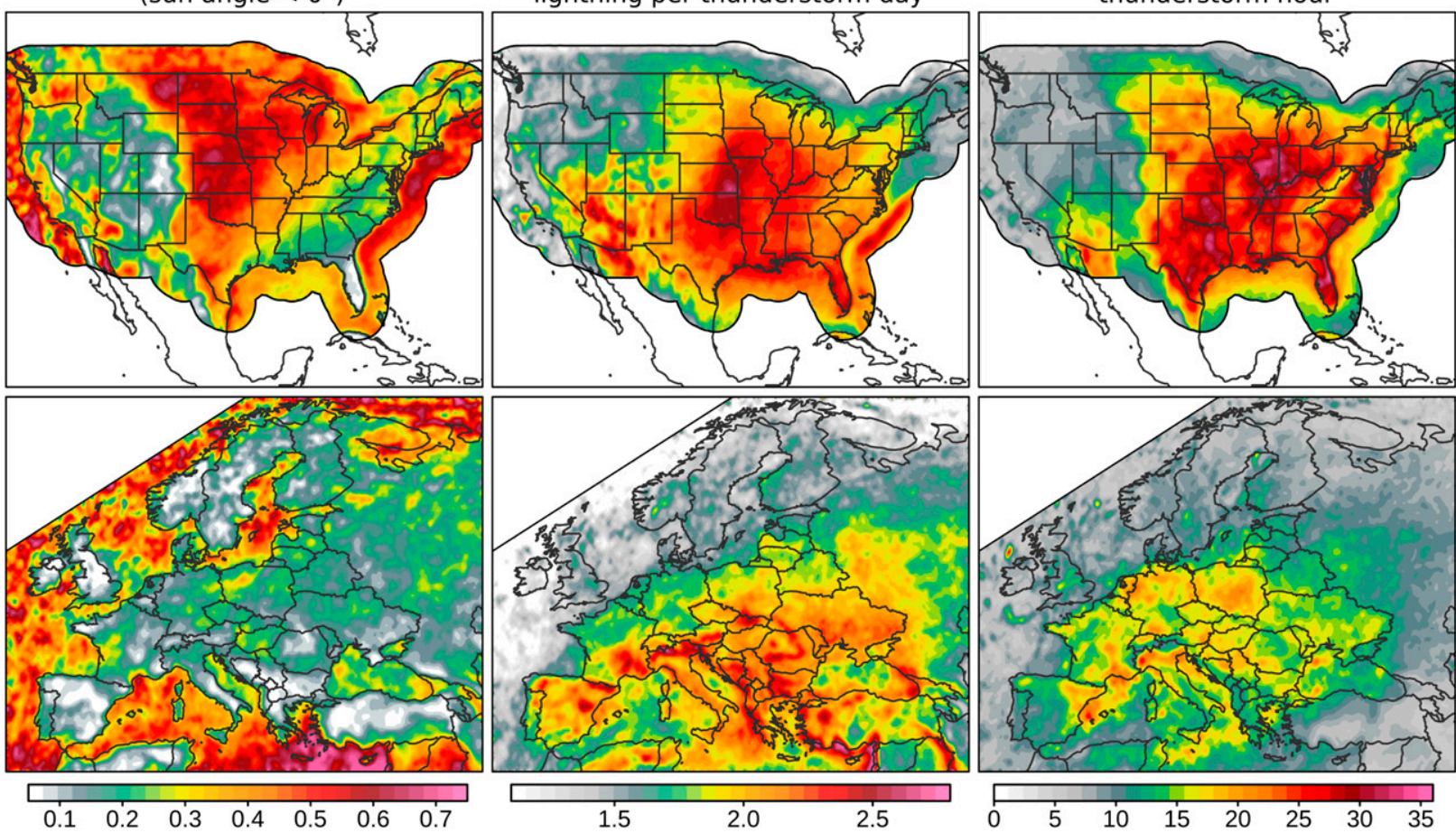

FIG. 9. (a) Annual mean number of hours with lightning, (b) fraction of nocturnal lightning, (c) mean number of hours with lightning per thunderstorm day, and (d) mean number of flashes per thunderstorm hour over the United States (1989-2018) and Europe (2006-18). Data are presented in $0.25^{\circ}$ boxes with a $0.75^{\circ} \times 0.75^{\circ}$ spatial smoother. Nocturnal lightning is defined when a sun angle for a specific grid and date is below $0^{\circ}$.

The share of very large hail events ranges from $5 \%$ over the Midwest up to almost $10 \%$ over the southern Great Plains, which also has the highest share of giant hail (1.2\%). Every analyzed region over Europe except the south has a higher share of very large and giant hail than the United States, suggesting a significant underreporting of small hail events in Europe. The highest share of very large hail is observed over eastern Europe (20\%), while a peak for giant hail occurs over the northwest $(1.9 \%)$.

In contrast to the ESWD, SPCSD provides estimated wind gusts in addition to measured peak wind gusts, leading to substantial differences (Fig. 12d). Over Europe the largest share of severe $\left(25-32 \mathrm{~m} \mathrm{~s}^{-1}\right)$ and extremely severe $\left(\geq 32 \mathrm{~m} \mathrm{~s}^{-1}\right)$ wind gusts is over the northwest $(27.7 \%$ and $6 \%$, respectively). 


\section{Fraction of hours with lightning associated with severe weather report (based on 1989-2018 for USA and 2006-2018 for EU)}

a
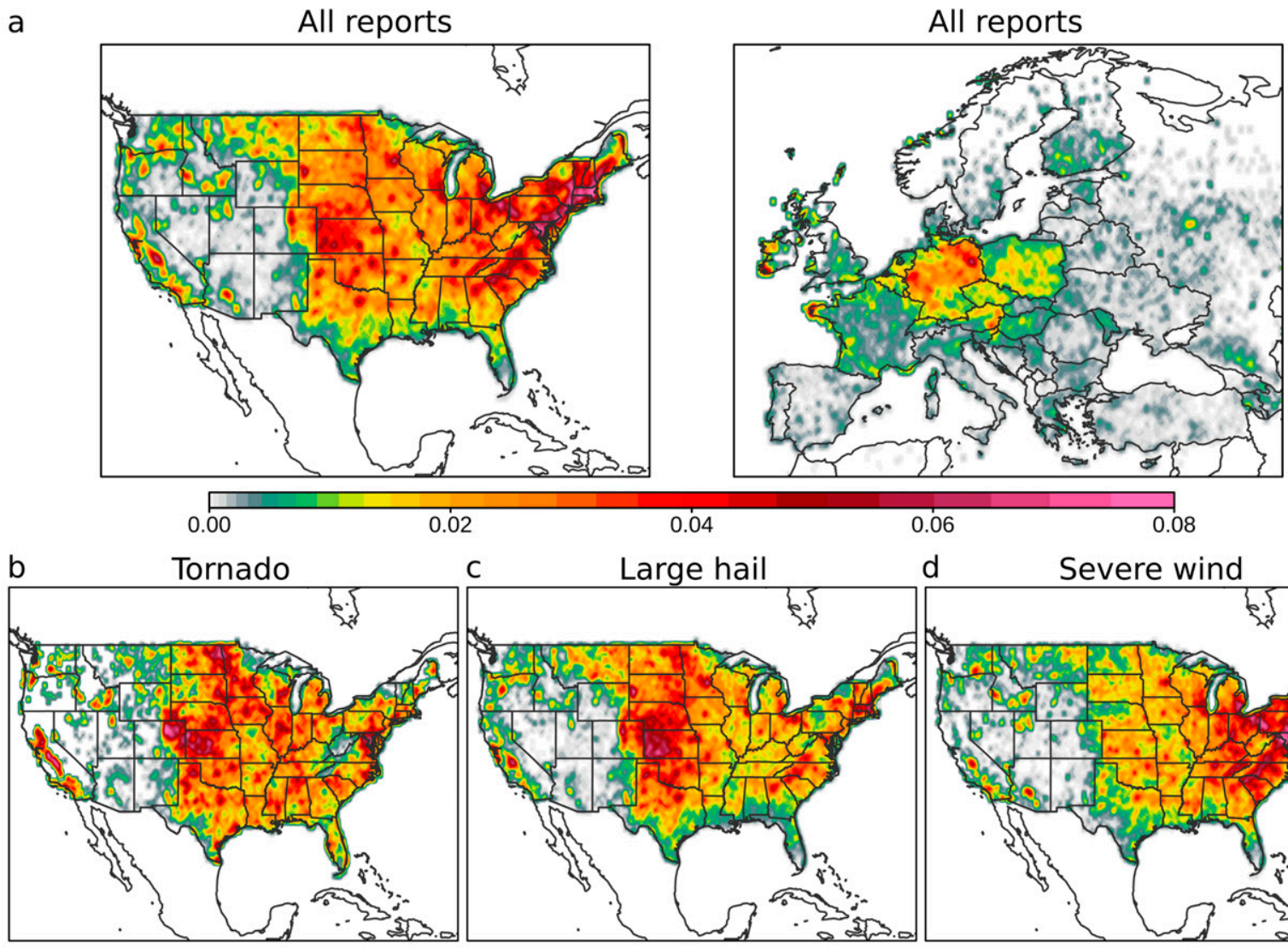

c Large hail

d Severe wind

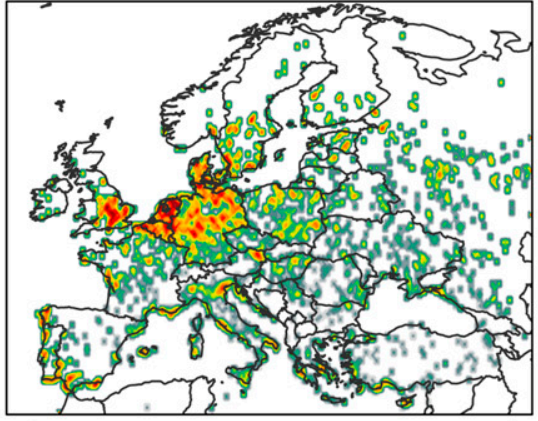

0.000

0.001

0.002

$0.003 \quad 0.004$
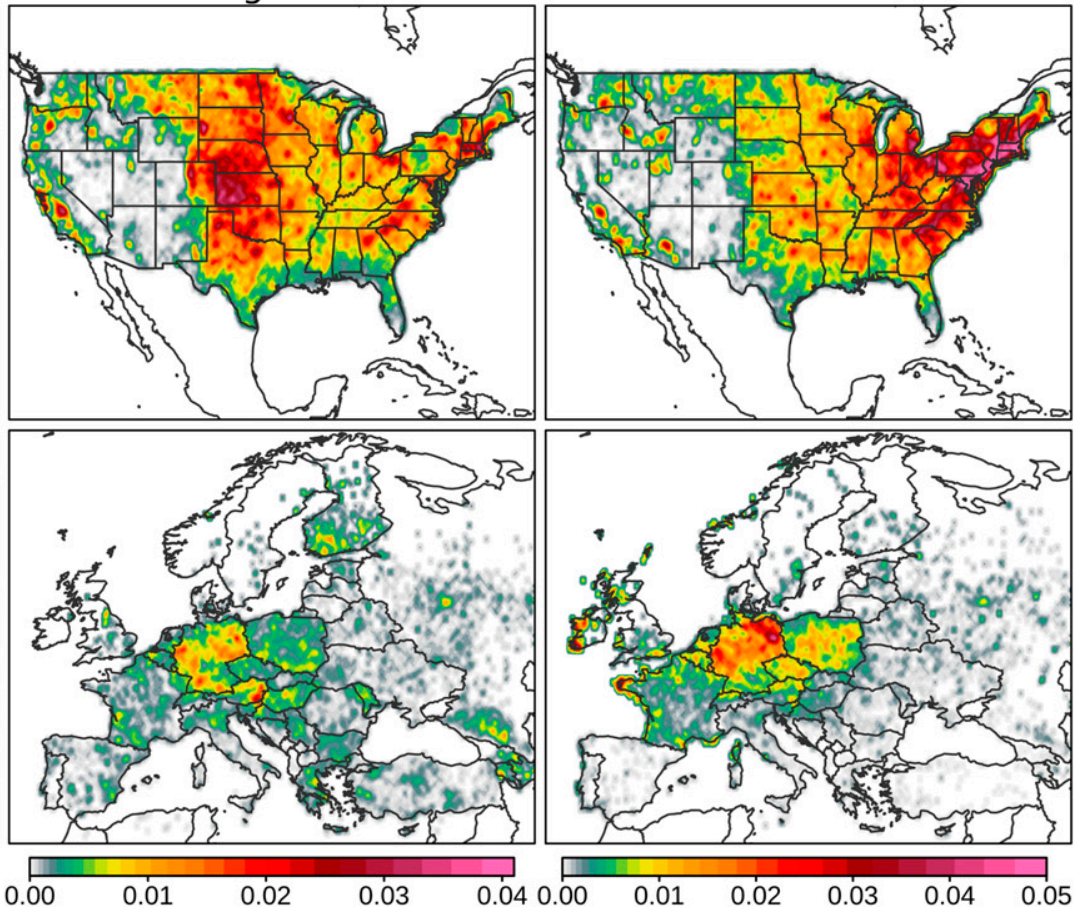

FIG. 10. Fraction of hours with lightning associated with (a) all reports, (b) tornadoes, (c) large hail, and (d) severe wind reports over the United States (1989-2018) and Europe (2006-18). Data are presented in $0.25^{\circ}$ boxes with a $0.75^{\circ} \times 0.75^{\circ}$ spatial smoother.

A lower share of severe and extremely severe wind gusts is observed over southern (13\% and $4.6 \%$, respectively), central (7.3\% and $1.7 \%$ ), and eastern Europe (3.2\% and $0.2 \%$ ). Over the United States the share of severe and extremely severe wind gusts is much higher, likely driven by $10 \%-30 \%$ of cases being derived from measurements (compared to $65 \%-95 \%$ over Europe), a result highlighted by Edwards et al. (2018). Severe wind gusts have the highest percentage over the Midwest (76\%) while the lowest is over the Southeast (63\%). As many as $13.8 \%$ of all extremely severe wind gusts are reported over mountains, mostly during the North American monsoon period in the late summer. Conversely, extremely severe wind gusts contribute only $3.7 \%$ of those reported over the southeastern United States.

Finally, we also assess the spatial distribution of the most extreme convective events (Fig. 13). The maximum hourly flash count highlights that in the corridor from southern Texas to Indiana storms may produce as many as 3000 flashes per hour in one grid cell. Conversely, European storms reach a 
Fraction of hours with lightning associated with severe weather report (based on 1989-2018 for USA and 2006-2018 for EU)
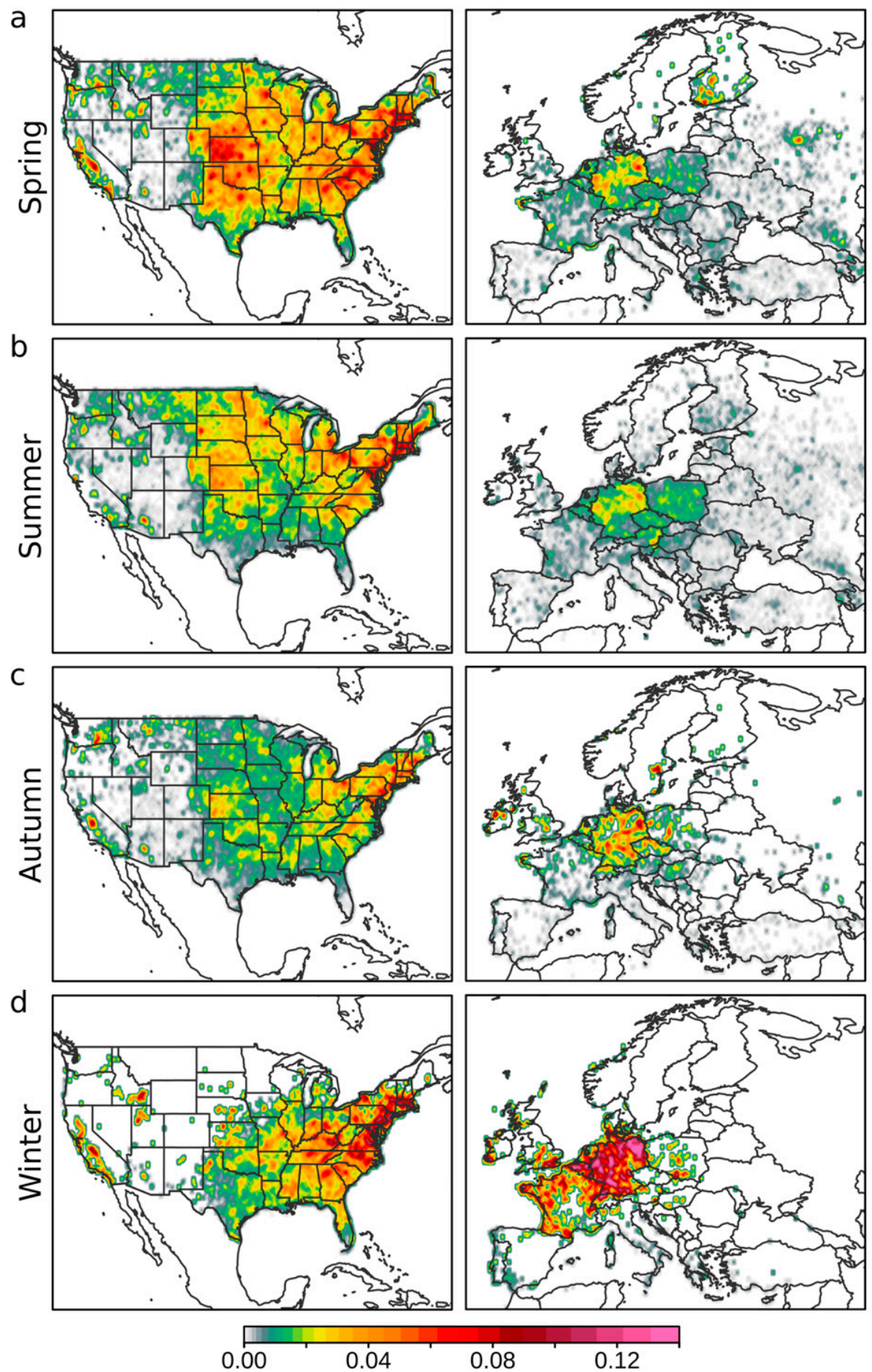

FIG. 11. Fraction of hours with lightning associated with tornadoes, large hail, and severe wind over the seasons in the United States (1989-2018) and Europe (2006-18). Data are presented in $0.25^{\circ}$ boxes with a $0.75^{\circ} \times 0.75^{\circ}$ spatial smoother. 


\section{Fractional distribution of intensity categories}

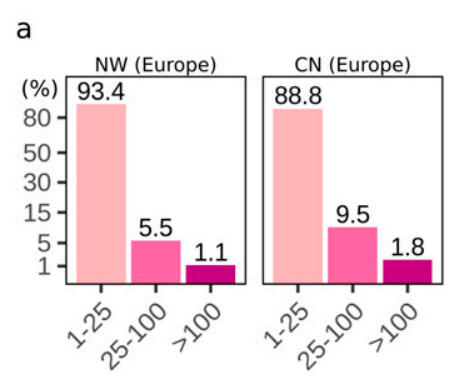

b

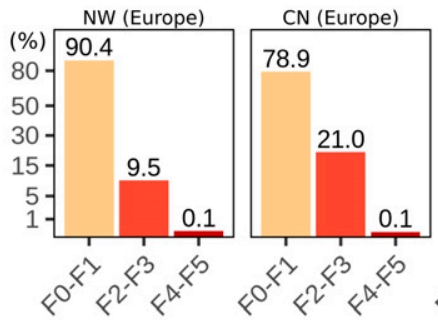

C

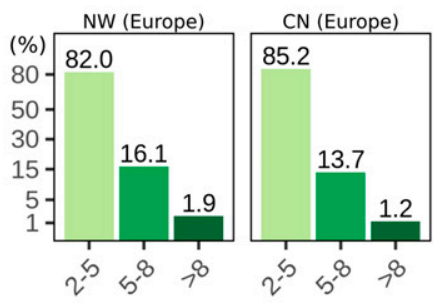

d

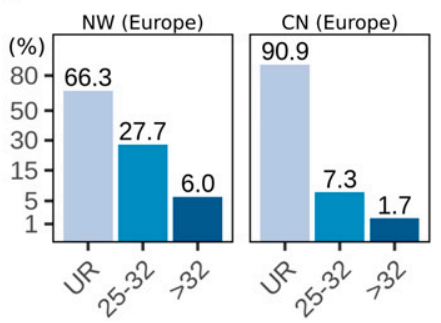

Lightning (flashes per $0.25^{\circ}$ grid per hour)

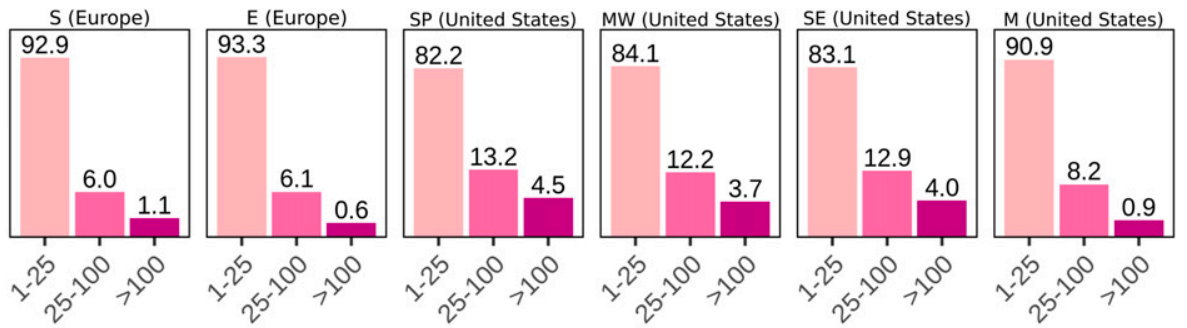

Tornadoes (F-scale rating)
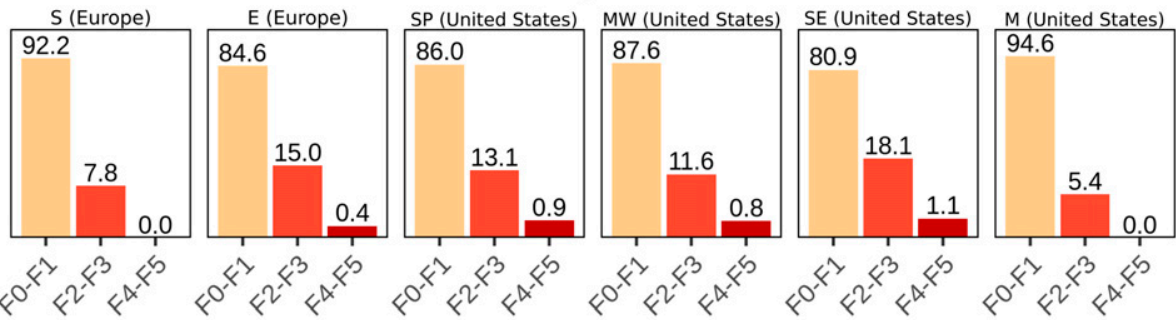

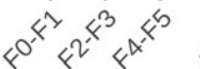

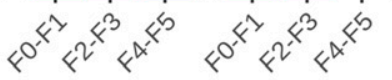

Large hail (diameter in $\mathrm{cm}$ )
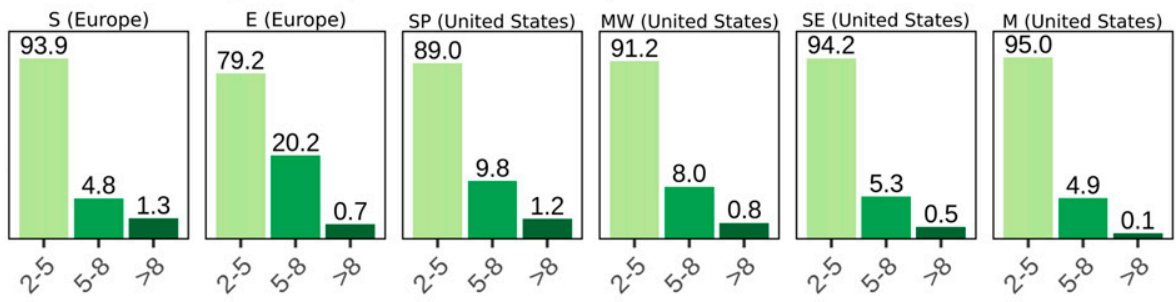

Severe wind (peak wind in $\mathrm{m} \mathrm{s}^{-1}$, UR - unrated)
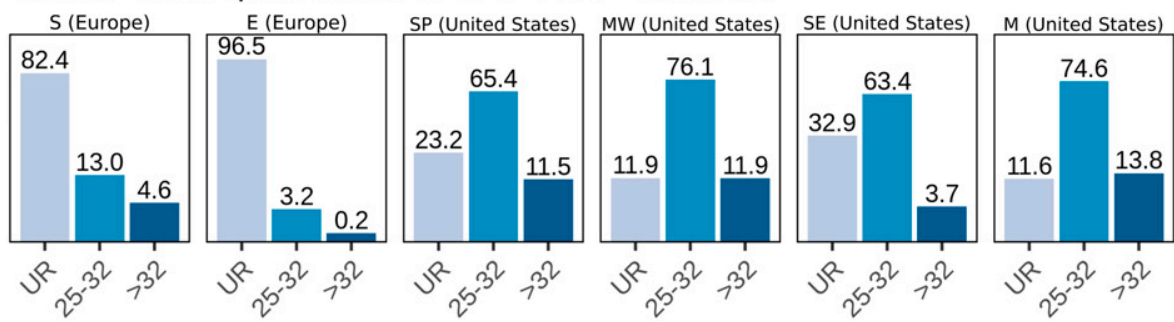

FIG. 12. Fractional distribution (\%) of intensity categories for (a) lightning, (b) tornadoes, (c) large hail, and (d) severe wind in division for hourly flash count per $0.25^{\circ}$ grid (lightning), F-scale rating (tornadoes), hailstone diameter ( $\mathrm{cm}$; large hail), and peak wind (m s ${ }^{-1}$; severe wind). The UR category denotes severe wind reports with peak wind gusts not provided.

maximum of 500-1000 flashes per hour, mostly over Mediterranean basin, and locally within central Europe (Fig. 13a). Comparing F3+ tornado reports unsurprisingly highlights the substantial difference in their frequency between the continents. Over the United States, F3 + tornadoes have occurred with some regularity east of the Rocky Mountains, while over Europe most such reports have been reported in a corridor from central France to western Russia (Fig. 13b). Giant hail events $(\geq 8 \mathrm{~cm})$ over the United States are confined mainly to the Great Plains, with a lower frequency over the East and uncommon in the West. Over Europe, giant hail has been reported in almost every region of the continent, but with substantially less frequency compared to the United States (Fig. 13c). High-end convective wind reports $\left(\geq 36 \mathrm{~m} \mathrm{~s}^{-1}\right)$ in Europe have almost exclusively occurred over the western and central part of the continent. This may be related to spatial reporting biases and a lack of information regarding measured peak wind gusts from other regions in ESWD. A much higher number of such events is reported over the United States, which may be due to the practice of estimating peak wind gusts, which often leads to overestimation (Edwards et al. 2018). The reporting of extremely severe thunderstorms over the western United States is very low compared to the Great Plains or the Southeast. 


\section{Spatial distribution of selected extreme convective events}

a
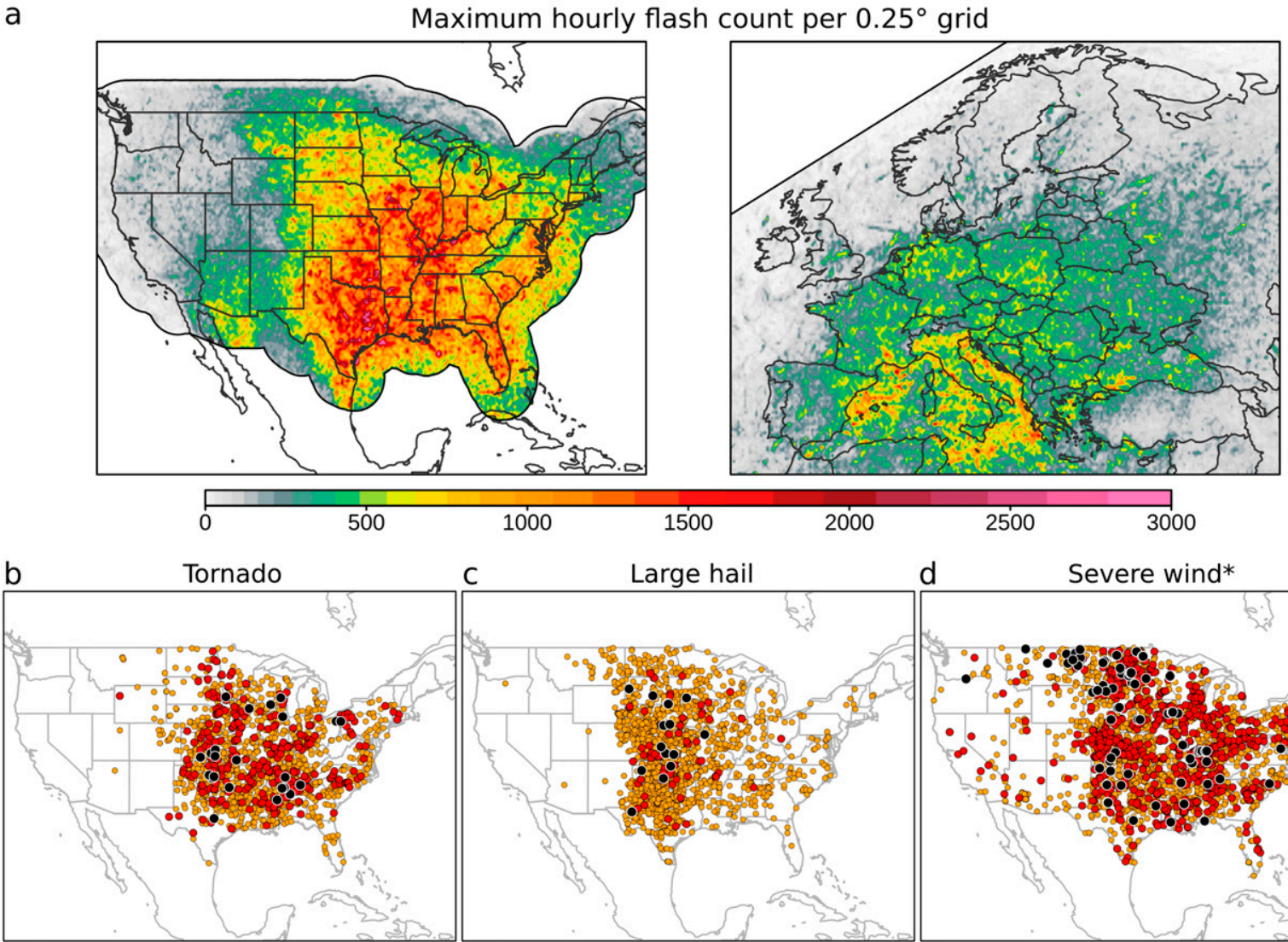

d Severe wind*

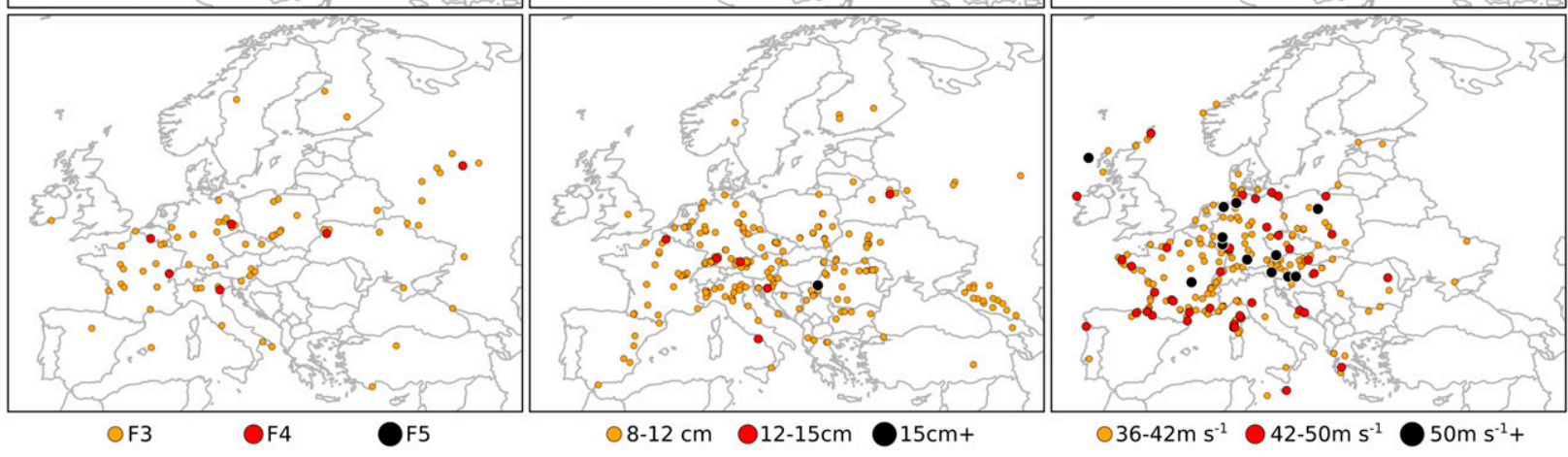

* - Due to lightning filter applied for ESWD severe wind reports only 2006-2018 data is displayed for both domains

FIG. 13. Spatial distribution of selected extreme convective events consisting of (a) maximum hourly flash count per $0.25^{\circ}$ grid, (b) tornadoes (F3-orange, F4-red, F5-black), (c) large hail (8-12 cm-orange, 12-15 cm-red, $\geq 15 \mathrm{~cm}$-black), and (d) severe wind (36$42 \mathrm{~m} \mathrm{~s}^{-1}$-orange, 42-50 $\mathrm{m} \mathrm{s}^{-1}$-red, $\geq 50 \mathrm{~m} \mathrm{~s}^{-1}$-black). Based on 1979-2018 data with exception for severe wind, which due to lightning filters applied for ESWD is limited to 2006-18 for Europe and for consistency also for the United States.

Among days (considered as 0600-0600 UTC for Europe and 0600-0600 CST for the United States) with the most notable thunderstorm activity we can list 17 July 2010 for Europe and 3 August 2004 for the United States with the highest number of detected flashes (214412 and 819724 respectively; Table 3). The highest daily number of significant $(\mathrm{F} 2+)$ tornadoes in Europe (a total of 8) was reported during the "Ivanovo tornado outbreak" (Finch and Bikos 2012; Chernokulsky and
Shikov 2018) on 9 June 1984. In comparison, there were 68 significant tornadoes during the "2011 Super Outbreak" occurring over the United States on 27 April 2011 (Knupp et al. 2014). Lower differences between both continents are observed for very large hail $(\geq 5 \mathrm{~cm})$ events. A severe hailstorm on 30 August 2016 near Moscow yielded 51 such reports compared to 53 during a widespread major severe weather outbreak over eastern United States on 2 March 2012. However, 
TABLE 3. Days with the peak frequency of specific hazards. A day is considered as 0600-0600 UTC for Europe and 0600-0600 CST for the United States.

\author{
Highest daily number of detected flashes \\ Europe: 214412 (17 Jul 2010) \\ United States: 819724 (3 Aug 2004) \\ Highest daily number of F2+ tornadoes \\ Europe: 8 (9 Jun 1984, the "Ivanovo tornado outbreak"; Finch and Bikos 2012; Chernokulsky and Shikhov 2018) \\ United States: 68 (27 Apr 2011, the "2011 Super Outbreak"; Knupp et al. 2014) \\ Highest daily number of $\geq 5$-cm hail reports \\ Europe: 51 (30 Aug 2016, severe weather outbreak near Moscow) \\ United States: 53 (2 Mar 2012, major severe weather outbreak over the eastern United States) \\ Highest daily number of severe wind reports \\ Europe: 1214 (11 Aug 2017, major derecho over the central Europe; Taszarek et al. 2019b) \\ United States: 1004 (29 Jun 2012, major derecho over the northeastern United States; Fierro et al. 2014)
}

this metric may be somewhat misleading given the filtering of storm data to remove duplicates, which are prevalent near highly populated areas. The highest daily numbers of wind reports over both continents were a result of derechoes (Corfidi et al. 2016). More than 1200 reports were associated with a derecho event over central Europe on 11 August 2017 (Taszarek et al. 2019b) and more than 1000 during a derecho over northeastern United States on 29 June 2012 (Fierro et al. 2014).

\section{Concluding remarks}

Thanks to the longer period for which lightning data have become available, and the continuing efforts to collect severe storm reports across both Europe and the United States, we could combine a large sample size of 1048843797 flashes from the NLDN and ATDnet lightning detection networks with 712995 severe weather reports from ESWD and SPCSD on a common grid of $0.25^{\circ}$ in 1 -h steps. Although prior work addressed climatological aspects of severe thunderstorms over Europe and the United States, no study has yet interlinked climatologies of lightning and severe storm data across both continents at hourly resolution. In prior studies, severe weather reports and lightning data were typically evaluated separately, and often with differing spatial and temporal resolutions, making direct comparisons and evaluations of the fractional likelihood troublesome. Here, we derive the spatiotemporal relationship between lightning and storm data and compare results between both continents. The evaluation of the annual, diurnal, and spatial distributions of lightning, tornado, large hail, and severe wind hazards led to many findings among which the most important are listed below.

- Each year between 75-200 h with thunderstorms occur over the central and eastern United States with a peak over Florida (200-250 h). Lightning activity over Europe ranges from 15 to $100 \mathrm{~h}$ with peaks over Italy and mountain ranges (Pyrenees, Alps, Carpathians, Dinaric Alps; 100-150 h).

- The highest activity over Europe occurs during summer over land, and during autumn across the Mediterranean. Over most of the central and eastern United States the peak time for tornadoes and large hail is in spring, and precedes the peak of lightning and severe wind by $1-2$ months. Over the southwestern United States, the American monsoon induces thunderstorm activity in the late summer. A bimodal distri- bution with a secondary cool-season peak is observed for tornadoes over the southeastern United States, and for severe wind events over northwestern Europe.

- Convective hazards occur typically in the late afternoon, with the exception of the Midwest and Great Plains, where nocturnal MCSs shift the maximum lightning threat to the night. Severe wind is typically delayed by $1-2 \mathrm{~h}$ relative to large hail and tornadoes. The highest fraction of nocturnal tornadoes occurs over the southeastern United States.

- The fraction of nocturnal lightning ranges typically from $15 \%$ to $30 \%$ over the land surface. The lowest values, below $10 \%$, are observed over Florida and mountain ranges, where diabatic heating is the primary mechanism. Nocturnal lightning is the most frequent over the Great Plains and the eastern Mediterranean (60\%-80\%).

- The highest fraction of lightning hours associated with tornado and large hail occurs in spring over the Great Plains. Convective wind reports peak over the eastern United States during winter. Over Europe, the highest fraction of thunderstorms with tornadoes are over the northwest, while with large hail and severe wind maximized across central Europe. Over both domains, wintertime lightning has the highest fraction of severe weather.

- Extreme convective events are considerably more frequent over the United States compared to Europe. The highest threat is across the Great Plains and Midwest, but violent tornadoes and extremely severe wind gusts are also reported over the East and Southeast. Significant severe storms over Europe are most often reported over western, central, and eastern parts of the continent. Underreporting across southern Europe may result in an underestimation of extreme events in this region.

- The results demonstrate a strong bias toward densely populated areas (especially considering large agglomerations) and therefore should be interpreted with caution.

Although spatial and temporal biases in severe weather reporting may be responsible for the large differences between Europe and the United States (not equivalent to the differences in the number of thunderstorm hours), a crucial factor is also the climatology of convective environments. The second part of the study (Taszarek et al. 2020) explores the environmental relationship to these hazards. More favorable overlap of instability and vertical wind shear over the United States promotes better organization of convection and thus more 
frequent severe weather. This leads to a conclusion that thunderstorms over Europe are not only less frequent, but they also have a lower potential in producing severe weather. However, as evident here, Europe is also vulnerable to the occurrence of high-end convective events such as $15 \mathrm{~cm}$ hail, $50 \mathrm{~m} \mathrm{~s}^{-1}$ severe wind, or F4-F5 tornadoes. Although these events are relatively rare, their potential should not be underestimated, especially considering high European population density, low societal severe weather awareness, and lack of advanced warning systems similar to those operating over the United States (Rauhala and Schulz 2009; Antonescu et al. 2017, 2018; Anderson-Frey et al. 2019).

Acknowledgments. This research was supported by grants from the Polish National Science Centre (2017/27/B/ST10/00297) and the Polish National Agency for Academic Exchange-The Bekker Programme (PPN/BEK/2018/1/00199). J. T. Allen acknowledges support from the National Science Foundation under Grant AGS-1945286. Groenemeijer was supported by Grant 01LP1525A1 (ARCS) from the German Ministry for Research and Education. We are grateful to the United Kingdom Met Office and NOAA National Severe Storms Laboratory for providing lightning data. The European Severe Storms Laboratory and the Storm Prediction Center are gratefully acknowledged for providing severe weather reports.

Data availability statement. The National Lightning Detection Network dataset was provided by NOAA National Severe Storms Laboratory and due to the proprietary nature of the data, cannot be made openly available; contact lightning@ou.edu for usage information. The ATDnet lightning dataset was provided by the United Kingdom Met Office and due to the proprietary nature of the data cannot be made openly available; contact debbie. osullivan@metoffice.gov.uk for usage information. United States severe weather reports are available at Storm Prediction Center Storm Data (https://www.spc.noaa.gov/wcm/). European severe weather reports are available at European Severe Weather Database (https://eswd.eu/).

\section{REFERENCES}

Adams, D. K., and A. C. Comrie, 1997: The North American monsoon. Bull. Amer. Meteor. Soc., 78, 2197-2214, https://doi.org/ 10.1175/1520-0477(1997)078<2197:TNAM > 2.0.CO;2.

Agdas, D., G. D. Webster, and F. J. Masters, 2012: Wind speed perception and risk. PLOS ONE, 7, e49944, https://doi.org/ 10.1371/journal.pone.0049944.

Albrecht, R. I., S. J. Goodman, D. E. Buechler, R. J. Blakeslee, and H. J. Christian, 2016: Where are the lightning hotspots on Earth? Bull. Amer. Meteor. Soc., 97, 2051-2068, https:// doi.org/10.1175/BAMS-D-14-00193.1.

Allen, J. T., 2018: Climate change and severe thunderstorms. Oxford Research Encyclopedia of Climate Science, https:// doi.org/10.1093/acrefore/9780190228620.013.62.

__ and M. K. Tippett, 2015: The characteristics of United States hail reports: 1955-2014. Electron. J. Severe Storms Meteor., 10, 3 , https://www.ejssm.org/ojs/index.php/ejssm/article/viewArticle/149.

,$- \longrightarrow$, Y. Kaheil, A. H. Sobel, C. Lepore, S. Nong, and A. Muehlbauer, 2017: An extreme value model for U.S. hail size. Mon. Wea. Rev., 145, 4501-4519, https://doi.org/10.1175/ MWR-D-17-0119.1.

- I. M. Giammanco, M. R. Kumjian, H. J. Punge, Q. Zhang, P. Groenemeijer, M. Kunz, and K. Ortega, 2020: Understanding hail in the Earth system. Rev. Geophys., 58, e2019RG000665, https://doi.org/10.1029/2019RG000665.

Amburn, S. A., and P. L. Wolf, 1997: VIL density as a hail indicator. Wea. Forecasting, 12, 473-478, https://doi.org/10.1175/15200434(1997)012<0473:VDAAHI>2.0.CO;2.

Anderson, G., and D. Klugmann, 2014: A European lightning density analysis using 5 years of ATDnet data. Nat. Haz. Earth Syst. Sci., 14, 815-829, https://doi.org/10.5194/nhess-14-815-2014.

Anderson-Frey, A. K., Y. P. Richardson, A. R. Dean, R. L. Thompson, and B. T. Smith, 2019: Characteristics of tornado events and warnings in the southeastern United States. Wea. Forecasting, 34, 1017-1034, https://doi.org/10.1175/WAF-D-18-0211.1.

Antonescu, B., and A. Bell, 2015: Tornadoes in Romania. Mon. Wea. Rev., 143, 689-701, https://doi.org/10.1175/MWR-D-14-00181.1.

_ - D. M. Schultz, F. Lomas, and T. Kühne, 2016: Tornadoes in Europe: Synthesis of the observational datasets. Mon. Wea. Rev., 144, 2445-2480, https://doi.org/10.1175/MWR-D-15-0298.1.

,,-- A. Holzer, and P. Groenemeijer, 2017: Tornadoes in Europe: An underestimated threat. Bull. Amer. Meteor. Soc., 98, 713-728, https://doi.org/10.1175/BAMS-D-16-0171.1.

- J. G. Fairman Jr., and D. M. Schultz, 2018: What is the worst that could happen? Reexamining the 24-25 June 1967 tornado outbreak over western Europe. Wea. Climate Soc., 10, 323340, https://doi.org/10.1175/WCAS-D-17-0076.1.

- D. M. Schultz, H. M. Ricketts, and D. Ene, 2019: Theories on tornado and waterspout formation in ancient Greece and Rome. Wea. Climate Soc., 11, 889-900, https://doi.org/10.1175/ WCAS-D-19-0057.1.

Apsley, M. L., K. J. Mulder, and D. M. Schultz, 2016: Reexamining the United Kingdom's greatest tornado outbreak: Forecasting the limited extent of tornadoes along a cold front. Wea. Forecasting, 31, 853-875, https://doi.org/10.1175/WAF-D-150131.1.

Ashley, W. S., 2007: Spatial and temporal analysis of tornado fatalities in the United States: 1880-2005. Wea. Forecasting, 22, 1214-1228, https://doi.org/10.1175/2007WAF2007004.1.

— , and A. W. Black, 2008: Fatalities associated with nonconvective high-wind events in the United States. J. Appl. Meteor. Climatol., 47, 717-725, https://doi.org/10.1175/2007JAMC1689.1.

— A. J. Krmenec, and R. Schwantes, 2008: Vulnerability due to nocturnal tornadoes. Wea. Forecasting, 23, 795-807, https:// doi.org/10.1175/2008WAF2222132.1.

Avgoustoglou, E., I. T. Matsangouras, I. Pytharoulis, N. Kamperakis, M. Mylonas, P. T. Nastos, and H. W. Bluestein, 2018: Numerical modeling analysis of the mesoscale environment conducive to two tornado events using the COSMO.Gr model over Greece. Atmos. Res., 208, 148-155, https://doi.org/10.1016/j.atmosres. 2017.07.022.

Bang, S. D., and D. J. Cecil, 2019: Constructing a multifrequency passive microwave hail retrieval and climatology in the GPM domain. J. Appl. Meteor. Climatol., 58, 1889-1904, https:// doi.org/10.1175/JAMC-D-19-0042.1.

Bedka, K., E. M. Murillo, C. R. Homeyer, B. Scarino, and H. Mersiovsky, 2018: The above-anvil cirrus plume: An important severe weather indicator in visible and infrared satellite imagery. Wea. Forecasting, 33, 1159-1181, https://doi.org/ 10.1175/WAF-D-18-0040.1.

Bennett, A., G. Callaghan, C. Gaffard, J. Nash, and R. Smout, 2010: The effect of changes in lightning waveform propagation 
characteristics on the UK Met office long range lightning location network (ATDnet). 21st Int. Lightning Detection Conf., Orlando, FL, Vaisala, http://www.vaisala.com/Vaisala \% 20Documents/Scientific\%20papers/3.Bennett,\%20Callaghan,\% 20Gaffard.pdf.

Bentley, M. L., and T. L. Mote, 1998: A climatology of derechoproducing mesoscale convective systems in the central and eastern United States, 1986-95. Part I: Temporal and spatial distribution. Bull. Amer. Meteor. Soc., 79, 2527-2540, https:// doi.org/10.1175/1520-0477(1998)079<2527:ACODPM>2.0.CO;2.

Blair, S. F., and J. W. Leighton, 2012: Creating high-resolution hail datasets using social media and post-storm ground surveys. Electron. J. Oper. Meteor., 13, 32-45, http://nwafiles.nwas.org/ ej/pdf/2012-EJ3.pdf.

- D. R. Deroche, J. M. Boustead, J. W. Leighton, B. L. Barjenbruch, and W. P. Gargan, 2011: A radar-based assessment of the detectability of giant hail. Electron. J. Severe Storms Meteor., 6 (7), https://www.ejssm.org/ojs/index.php/ ejssm/article/viewArticle/87.

_- and Coauthors, 2017: High-resolution hail observations: Implications for NWS warning operations. Wea. Forecasting, 32, 1101-1119, https://doi.org/10.1175/WAF-D-16-0203.1.

Brázdil, R., K. Chromá, L. Dolák, O. Kotyza, L. Řezníčková, P. Dobrovolný, and Z. Černoch, 2019: Spatiotemporal variability of tornadoes in the Czech Lands, 1801-2017. Theor. Appl. Climatol., 136, 1233-1248, https://doi.org/10.1007/s00704-018-2553-y.

Brooks, H. E., 2009: Proximity soundings for severe convection for Europe and the United States from reanalysis data. Atmos. Res., 93, 546-553, https://doi.org/10.1016/j.atmosres.2008.10.005.

— , G. W. Carbin, and P. T. Marsh, 2014: Increased variability of tornado occurrence in the United States. Science, 346, 349352, https://doi.org/10.1126/science.1257460.

— vective storm research and forecasting. Meteor. Monogr., No. 59, Amer. Meteor. Soc., https://doi.org/10.1175/AMSMONOGRAPHSD-18-0026.1.

Cecil, D. J., 2009: Passive microwave brightness temperatures as proxies for hailstorms. J. Appl. Meteor. Climatol., 48, 12811286, https://doi.org/10.1175/2009JAMC2125.1.

__ and C. B. Blankenship, 2012: Toward a global climatology of severe hailstorms as estimated by satellite passive microwave imagers. J. Climate, 25, 687-703, https://doi.org/10.1175/JCLID-11-00130.1.

— D. E. Buechler, and R. J. Blakeslee, 2015: TRMM LIS climatology of thunderstorm occurrence and conditional lightning flash rates. J. Climate, 28, 6536-6547, https://doi.org/ 10.1175/JCLI-D-15-0124.1.

Celiński-Mysław, D., and D. Matuszko, 2014: An analysis of selected cases of derecho in Poland. Atmos. Res., 149, 263-281, https://doi.org/10.1016/j.atmosres.2014.06.016.

Changnon, S. A., 1999: Data and approaches for determining hail risk in the contiguous United States. J. Appl. Meteor., 38, 1730-1739, https://doi.org/10.1175/1520-0450(1999)038<1730: DAAFDH $>2.0 . \mathrm{CO} ; 2$.

Chernokulsky, A., and A. Shikhov, 2018: 1984 Ivanovo tornado outbreak: Determination of actual tornado tracks with satellite data. Atmos. Res., 207, 111-121, https://doi.org/10.1016/ j.atmosres.2018.02.011.

— , and Coauthors, 2020: Tornadoes in northern Eurasia: From the middle age to the information era. Mon. Wea. Rev., 148, 3081-3110, https://doi.org/10.1175/MWR-D-19-0251.1.

Cintineo, J. L., T. M. Smith V. Lakshmanan, H. E. Brooks, and K. L. Ortega, 2012: An objective high-resolution hail climatology of the contiguous United States. Wea. Forecasting, 27, 1235-1248, https://doi.org/10.1175/WAF-D-11-00151.1.

Coffer, B. E., M. D. Parker, R. L. Thompson, B. T. Smith, and R. E. Jewell, 2019: Using near-ground storm relative helicity in supercell tornado forecasting. Wea. Forecasting, 34, 1417-1435, https://doi.org/10.1175/WAF-D-19-0115.1.

Corfidi, S. F., M. C. Coniglio, A. E. Cohen, and C. M. Mead, 2016: A proposed revision to the definition of "derecho." Bull. Amer. Meteor. Soc., 97, 935-949, https://doi.org/10.1175/ BAMS-D-14-00254.1.

Cummins, K. L., and M. J. Murphy, 2009: An overview of lightning locating systems: History, techniques, and data uses, with an in-depth look at the US NLDN. IEEE Trans. Electromagn. Compat., 51, 499-518, https://doi.org/10.1109/TEMC.2009. 2023450.

$\longrightarrow,-$, E. A. Bardo, W. L. Hiscox, R. B. Pyle, and A. E. Pifer, 1998: A combined TOA/MDF technology upgrade of the U.S. National Lightning Detection Network. J. Geohpys. Res. Atmos., 103, 9035-9044, https://doi.org/10.1029/98JD00153.

Dobur, J. C., 2005: A comparison of severe thunderstorm warning verification statistics and population density within the NWS Atlanta county warning area. Preprints, Fourth Annual Severe Storms Symp., Starkville, MS, East Mississippi Chapter National Weather Association, https://www.weather.gov/ media/ffc/SEconf.pdf.

Doswell, C. A., III, 2003: Societal impacts of severe thunderstorms and tornadoes: Lessons learned and implications for Europe. Atmos. Res., 67-68, 135-152, https://doi.org/10.1016/S01698095(03)00048-6.

- H. E. Brooks, and M. P. Kay, 2005: Climatological estimates of daily local nontornadic severe thunderstorm probability for the United States. Wea. Forecasting, 20, 577-595, https:// doi.org/10.1175/WAF866.1.

,-- , and N. Dotzek, 2009: On the implementation of the enhanced Fujita scale in the USA. Atmos. Res., 93, 554-563, https://doi.org/10.1016/j.atmosres.2008.11.003.

Dotzek, N., 2003: An updated estimate of tornado occurrence in Europe. Atmos. Res., 67-68, 153 -161, https://doi.org/10.1016/ S0169-8095(03)00049-8

—, P. Groenemeijer, B. Feuerstein, and A. M. Holzer, 2009: Overview of ESSL's severe convective storms research using the European Severe Weather Database ESWD. Atmos. Res., 93, 575-586, https://doi.org/10.1016/j.atmosres.2008.10.020.

Edwards, R., J. G. LaDue, J. T. Ferree, K. Scharfenberg, C. Maier, and W. L. Coulbourne, 2013: Tornado intensity estimation: Past, present, and future. Bull. Amer. Meteor. Soc., 94, 641653, https://doi.org/10.1175/BAMS-D-11-00006.1.

_ J. T. Allen, and G. W. Carbin, 2018: Reliability and climatological impacts of convective wind estimations. J. Appl. Meteor. Climatol., 57, 1825-1845, https://doi.org/10.1175/ JAMC-D-17-0306.1.

Elmore, K. L., Z. L. Flamig, V. Lakshmanan, B. T. Kaney, V. Farmer, H. D. Reeves, and L. P. Rothfusz, 2014: MPING: Crowd-sourcing weather reports for research. Bull. Amer. Meteor. Soc., 95, 1335-1342, https://doi.org/10.1175/BAMS-D-13-00014.1.

Elsner, J. B., S. C. Elsner, and T. H. Jagger, 2015: The increasing efficiency of tornado days in the United States. Climate Dyn., 45, 651-659, https://doi.org/10.1007/s00382-014-2277-3.

Enno, S. E., G. Anderson, and J. Sugier, 2016: ATDnet detection efficiency and cloud lightning detection characteristics from comparison with the HyLMA during HyMeX SOP1. J. Atmos. Oceanic Technol., 33, 1899-1911, https://doi.org/10.1175/ JTECH-D-15-0256.1. 
_ J. Sugier, R. Alber, and M. Seltzer, 2020: Lightning flash density in Europe based on 10 years of ATDnet data. Atmos. Res., 235, 104769, https://doi.org/10.1016/j.atmosres.2019.104769.

Feuerstein, B., P. Groenemeijer, E. Dirksen, M. Hubrig, A. M. Holzer, and N. Dotzek, 2011: Towards an improved wind speed scale and damage description adapted for central Europe. Atmos. Res., 100, 547-564, https://doi.org/10.1016/ j.atmosres.2010.12.026.

Fierro, A. O., J. Gao, C. L. Ziegler, E. R. Mansell, D. R. MacGorman, and S. R. Dembek, 2014: Evaluation of a cloudscale lightning data assimilation technique and a 3DVAR method for the analysis and short-term forecast of the 29 June 2012 derecho event. Mon. Wea. Rev., 142, 183-202, https:// doi.org/10.1175/MWR-D-13-00142.1.

Finch, J., and D. Bikos, 2012: Russian tornado outbreak of 9 June 1984. Electron. J. Severe Storms Meteor., 7 (4), https://www.ejssm. org/ojs/index.php/ejssm/article/view/98.

Fleenor, S. A., C. J. Biagi, K. L. Cummins, E. P. Krider, and X. M. Shao, 2009: Characteristics of cloud-to-ground lightning in warm-season thunderstorms in the central Great Plains. Atmos. Res., 91, 333-352, https://doi.org/10.1016/j.atmosres.2008.08.011.

Fluck, E., M. Kunz, P. Geissbuehler, and S. P. Ritz, 2020: Radarbased assessment of hail frequency in Europe. Nat. Hazards Earth Syst. Sci. Discuss., https://doi.org/10.5194/NHESS-2020-138.

Fujita, T. T., 1971: Proposed characterization of tornadoes and hurricanes by area and intensity, SMRP Tech Rep. 91, University of Chicago, $42 \mathrm{pp}$.

Galanaki, E., K. Lagouvardos, V. Kotroni, E. Flaounas, and A. Argiriou, 2018: Thunderstorm climatology in the Mediterranean using cloud-to-ground lightning observations. Atmos. Res., 207, 136-144, https://doi.org/10.1016/j.atmosres.2018.03.004.

Gatzen, C., 2011: A 10-year climatology of cold-season narrow cold-frontal rainbands in Germany. Atmos. Res., 100, 366-370, https://doi.org/10.1016/j.atmosres.2010.09.018.

—, A. H. Fink, D. M. Schultz, and J. G. Pinto, 2020: An 18-year climatology of derechos in Germany. Nat. Hazards Earth Syst. Sci., 20, 1335-1351, https://doi.org/10.5194/nhess-20-1335-2020.

Geerts, B., and Coauthors, 2017: The 2015 Plains Elevated Convection at Night field project. Bull. Amer. Meteor. Soc., 98, 767-786, https://doi.org/10.1175/BAMS-D-15-00257.1.

Gensini, V. A., A. M. Haberlie, and P. T. Marsh, 2020: Practically perfect hindcasts of severe convective storms. Bull. Amer. Meteor. Soc., 101, E1259-E1278, https://doi.org/10.1175/BAMSD-19-0321.1.

Graham, M., and W. H. Dutton, Eds., 2019: Society and the Internet: How Networks of Information and Communication Are Changing Our Lives. 2nd ed. Oxford University Press, 480 pp.

Grazulis, T. P., 1991: Significant Tornadoes, 1880-1989: A Chronology of Events. Environmental Films, 1326 pp.

Groenemeijer, P., and T. Kühne, 2014: A climatology of tornadoes in Europe: Results from the European Severe Weather Database. Mon. Wea. Rev., 142, 4775-4790, https://doi.org/ 10.1175/MWR-D-14-00107.1.

— , and Coauthors, 2017: Severe convective storms in Europe: Ten years of research and education at the European Severe Storms laboratory. Bull. Amer. Meteor. Soc., 98, 2641-2651, https://doi.org/10.1175/BAMS-D-16-0067.1.

Gropp, M. E., and C. E. Davenport, 2018: The impact of the nocturnal transition on the lifetime and evolution of supercell thunderstorms in the Great Plains. Wea. Forecasting, 33, 10451061, https://doi.org/10.1175/WAF-D-17-0150.1.

Grünwald, S., and H. E. Brooks, 2011: Relationship between sounding derived parameters and the strength of tornadoes in
Europe and the USA from reanalysis data. Atmos. Res., 100, 479-488, https://doi.org/10.1016/j.atmosres.2010.11.011.

Haberlie, A. M., and W. S. Ashley, 2018: Climatological representation of mesoscale convective systems in a dynamically downscaled climate simulation. Int. J. Climatol., 39, 11441153, https://doi.org/10.1002/joc.5880.

— convective systems in the United States. J. Climate, 32, 15911606, https://doi.org/10.1175/JCLI-D-18-0559.1.

Hamid, K., 2012: Investigation of the passage of a derecho in Belgium. Atmos. Res., 107, 86-105, https://doi.org/10.1016/ j.atmosres.2011.12.013.

Holzer, A. M., P. Groenemeijer, K. Riemann-Campe, and B. Antonescu, 2017: Experience after 1 year of EWOB. Proc., Ninth European Conf. on Severe Storms (ECSS 2017), Pula, Croatia, https://presentations.copernicus.org/ ECSS2017/ECSS2017-188_presentation.pdf.

Johnson, A. W., and K. E. Sugden, 2014: Evaluation of soundingderived thermodynamic and wind-related parameters associated with large hail events. Electron. J. Severe Storms Meteor., 9 (5), https://www.ejssm.org/ojs/index.php/ejssm/article/viewArticle/ 137.

Kahraman, A., and P. M. Markowski, 2014: Tornado climatology of Turkey. Mon. Wea. Rev., 142, 2345-2352, https://doi.org/10.1175/ MWR-D-13-00364.1.

— S. Tilev-Tanriover, M. Kadioglu, D. M. Schultz, and P. M. Markowski, 2016: Severe hail climatology of Turkey. Mon. Wea. Rev., 144, 337-346, https://doi.org/10.1175/MWR-D-150337.1.

Kelly, D. L., J. T. Schaefer, and C. A. Doswell III, 1985: Climatology of nontornadic severe thunderstorm events in the United States. Mon. Wea. Rev., 113, 1997-2014, https:// doi.org/10.1175/1520-0493(1985)113<1997:CONSTE>2.0. $\mathrm{CO} ; 2$.

Kingfield, D. M., K. M. Calhoun, and K. M. de Beurs, 2017: Antenna structures and cloud-to-ground lightning location: 1995-2015. Geophys. Res. Lett., 44, 5203-5212, https://doi.org/ 10.1002/2017GL073449.

Knupp, K. R., and Coauthors, 2014: Meteorological overview of the devastating 27 April 2011 tornado outbreak. Bull. Amer. Meteor. Soc., 95, 1041-1062, https://doi.org/10.1175/BAMS-D11-00229.1.

Koehler, T. L., 2020: Cloud-to-ground lightning flash density and thunderstorm day distributions over the contiguous United States derived from NLDN measurements: 1993-2018. Mon. Wea. Rev., 148, 313-332, https://doi.org/10.1175/MWR-D-190211.1.

Kolendowicz, L., 2012: Synoptic patterns associated with thunderstorms in Poland. Meteor. Z., 21, 145-156, https://doi.org/ 10.1127/0941-2948/2012/0272.

Krennert, T., G. Pistotnik, R. Kaltenberger, and C. Csekits, 2018: Crowdsourcing of weather observations at national meteorological and hydrological services in Europe. Adv. Sci. Res., 15, 71-76, https://doi.org/10.5194/asr-15-71-2018.

Krocak, M. J., and H. E. Brooks, 2018: Climatological estimates of hourly tornado probability for the United States. Wea. Forecasting, 33, 59-69, https://doi.org/10.1175/WAF-D-17-0123.1.

Kunz, M., and M. Puskeiler, 2010: High-resolution assessment of the hail hazard over complex terrain from radar and insurance data. Meteor. Z., 19, 427-439, https://doi.org/10.1127/09412948/2010/0452. 
— and P. I. S. Kugel, 2015: Detection of hail signatures from single-polarization C-band radar reflectivity. Atmos. Res., 153, 565-577, https://doi.org/10.1016/j.atmosres.2014.09.010.

—, U. Blahak, J. Handwerker, M. Schmidberger, H. J. Punge, S. Mohr, E. Fluck, and K. M. Bedka, 2018: The severe hailstorm in southwest Germany on 28 July 2013: Characteristics, impacts and meteorological conditions. Quart. J. Roy. Meteor. Soc., 144, 231-250, https://doi.org/10.1002/QJ.3197.

—, J. Wandel, E. Fluck, S. Baumstark, S. Mohr, and S. Schemm, 2020: Ambient conditions prevailing during hail events in central Europe. Nat. Hazards Earth Syst. Sci., 20, 1867-1887, https://doi.org/10.5194/nhess-20-1867-2020.

Lee, A. C. L., 1986: An operational system for the remote location of lightning flashes using a VLF arrival time difference technique. J. Atmos. Ocean. Technol., 3, 630-642, https://doi.org/ 10.1175/1520-0426(1986)003<0630:AOSFTR > 2.0.CO;2.

Marzban, C., and A. Witt, 2001: A Bayesian neural network for severe-hail size prediction. Wea. Forecasting, 16, 600-610, https:// doi.org/10.1175/1520-0434(2001)016<0600:ABNNFS > 2.0.CO;2.

Mathias, L., V. Ermert, F. D. Kelemen, P. Ludwig, and J. G. Pinto, 2017: Synoptic analysis and hindcast of an intense bow echo in western Europe: The 9 June 2014 storm. Wea. Forecasting, 32, 1121-1141, https://doi.org/10.1175/WAF-D-16-0192.1.

—, P. Ludwig, and J. G. Pinto, 2019: Synoptic-scale conditions and convection-resolving hindcast experiments of a coldseason derecho on 3 January 2014 in western Europe. Nat. Hazards Earth Syst. Sci., 19, 1023-1040, https://doi.org/ 10.5194/nhess-19-1023-2019.

Matsangouras, I. T., P. T. Nastos, and I. Pytharoulis, 2016: Study of the tornado event in Greece on March 25, 2009: Synoptic analysis and numerical modeling using modified topography. Atmos. Res., 169, 566-583, https://doi.org/10.1016/j.atmosres.2015.08.010.

,,-- H. B. Bluestein, I. Pytharoulis, K. Papachristopoulou, and M. M. Miglietta, 2017: Analysis of waterspout environmental conditions and of parent-storm behaviour based on satellite data over the southern Aegean Sea of Greece. Int. J. Climatol., 37, 1022-1039, https://doi.org/10.1002/joc.4757.

Medici, G., K. L. Cummins, D. J. Cecil, W. J. Koshak, and S. D. Rudlosky, 2017: The intracloud lightning fraction in the contiguous United States. Mon. Wea. Rev., 145, 4481-4499, https://doi.org/10.1175/MWR-D-16-0426.1.

Miglietta, M. M., and R. Rotunno, 2016: An EF3 multivortex tornado over the Ionian region: Is it time for a dedicated warning system over Italy? Bull. Amer. Meteor. Soc., 97, 337-344, https://doi.org/10.1175/BAMS-D-14-00227.1.

—_, and I. T. Matsangouras, 2018: An updated "climatology" of tornadoes and waterspouts in Italy. Int. J. Climatol., 38, 36673683, https://doi.org/10.1002/joc.5526.

__ J. Mazon, and R. Rotunno, 2017: Numerical simulations of a tornadic supercell over the Mediterranean. Wea. Forecasting, 32, 1209-1226, https://doi.org/10.1175/WAF-D-16-0223.1.

Mohr, S., M. Kunz, and B. Geyer, 2015: Hail potential in Europe based on a regional climate model hindcast. Geophys. Res. Lett., 42, 10 904-10 912, https://doi.org/10.1002/2015GL067118.

,$- \ldots$, A. Richter, and B. Ruck, 2017: Statistical characteristics of convective wind gusts in Germany. Nat. Hazards Earth Syst. Sci., 17, 957-969, https://doi.org/10.5194/nhess-17-957-2017.

_, J. Wandel, S. Lenggenhager, and O. Martius, 2019: Relationship between atmospheric blocking and warm-season thunderstorms over western and central Europe. Quart. J. Roy. Meteor. Soc., 145, 3040-3056, https://doi.org/10.1002/qj.3603.

— , and Coauthors, 2020: The role of large-scale dynamics in an exceptional sequence of severe thunderstorms in Europe
May-June 2018. Wea. Climate Dynam., 1, 325-348, https:// doi.org/10.5194/wcd-1-325-2020.

Morel, C., and S. Senesi, 2002: A climatology of mesoscale convective systems over Europe using satellite infrared imagery. II: Characteristics of European mesoscale convective systems. Quart. J. Roy. Meteor. Soc., 128, 1973-1995, https://doi.org/ 10.1256/003590002320603494.

Mulder, K. J., and D. M. Schultz, 2015: Climatology, storm morphologies, and environments of tornadoes in the British Isles: 1980-2012. Mon. Wea. Rev., 143, 2224-2240, https://doi.org/ 10.1175/MWR-D-14-00299.1.

Murillo, E. M., and C. R. Homeyer, 2019: Severe hail fall and hailstorm detection using remote sensing observations. J. Appl. Meteor. Climatol., 58, 947-970, https://doi.org/10.1175/JAMCD-18-0247.1.

Nag, A., M. J. Murphy, K. L. Cummins, A. E. Pifer, and J. A. Cramer, 2014: Recent evolution of the U.S. National Lightning Detection Network. 23rd Int. Lightning Detection Conf. and Fifth Int. Lightning Meteor. Conf., Tucson, AZ, Vaisala, https:// my.vaisala.net/Vaisala \%20Documents/Scientific\%20papers/ 2014\%20ILDC\%20ILMC/ILDC-Wednesday/Nag\%20et\%20alRecent\%20Evolution \%20of\%20the \%20U.S.\%20National \%20Lightning\%20Detection\%20Network-2014-ILDC-ILMC.pdf.

Nisi, L., O. Martius, A. Hering, M. Kunz, and U. Germann, 2016: Spatial and temporal distribution of hailstorms in the Alpine region: A long-term, high resolution, radar-based analysis. Quart. J. Roy. Meteor. Soc., 142, 1590-1604, https://doi.org/10.1002/qj.2771.

Ortega, K. L., T. M. Smith, K. L. Manross, K. A. Scharfenberg, A. Witt, A. G. Kolodziej, and J. J. Gourley, 2009: The Severe Hazards Analysis and Verification Experiment. Bull. Amer. Meteor. Soc., 90, 1519-1530, https://doi.org/10.1175/2009BAMS2815.1.

Pewsey, A., M. Neuhäuser, and G. D. Ruxton, 2013: Circular Statistics in R. Oxford University Press, 198 pp.

Pilguj, N., M. Taszarek, Ł. Pajurek, and M. Kryza, 2019: Highresolution simulation of an isolated tornadic supercell in Poland on 20 June 2016. Atmos. Res., 218, 145-159, https:// doi.org/10.1016/j.atmosres.2018.11.017.

Piper, D., M. Kunz, F. Ehmele, S. Mohr, B. Mühr, A. Kron, and J. Daniell, 2016: Exceptional sequence of severe thunderstorms and related flash floods in May and June 2016 in Germany_Part 1: Meteorological background. Nat. Hazards Earth Syst. Sci., 16, 28352850, https://doi.org/10.5194/nhess-16-2835-2016.

,,-- J. T. Allen, and S. Mohr, 2019: Investigation of the temporal variability of thunderstorms in central and western Europe and the relation to large-scale flow and teleconnection patterns. Quart. J. Roy. Meteor. Soc., 145, 3644-3666, https:// doi.org/10.1002/qj.3647.

Poelman, D. R., F. Honoré, G. Anderson, and S. Pedeboy, 2013a: Comparing a regional, subcontinental, and long-range lightning location system over the Benelux and France. J. Atmos. Oceanic Technol., 30, 2394-2405, https://doi.org/10.1175/ JTECH-D-12-00263.1.

— W. Schulz, and C. Vergeiner, 2013b: Performance characteristics of distinct lightning detection networks covering Belgium. J. Atmos. Oceanic Technol., 30, 942-951, https:// doi.org/10.1175/JTECH-D-12-00162.1.

Potvin, C. K., C. Broyles, P. S. Skinner, H. E. Brooks, and E. Rasmussen, 2019: A Bayesian hierarchical modeling framework for correcting reporting bias in the U.S. tornado database. Wea. Forecasting, 34, 15-30, https://doi.org/10.1175/ WAF-D-18-0137.1.

Púčik, T., C. Castellano, P. Groenemeijer, T. Kühne, A. T. Rädler, B. Antonescu, and E. Faust, 2019: Large hail incidence and its 
economic and societal impacts across Europe. Mon. Wea. Rev., 147, 3901-3916, https://doi.org/10.1175/MWR-D-19-0204.1.

Punge, H. J., and M. Kunz, 2016: Hail observations and hailstorm characteristics in Europe: A review. Atmos. Res., 176-177, 159-184, https://doi.org/10.1016/j.atmosres.2016.02.012.

_ based stochastic event catalog for hail in Europe. Nat. Hazards, 73, 1625-1645, https://doi.org/10.1007/s11069-014-1161-0.

,,,--- and A. Reinbold, 2017: Hail frequency estimation across Europe based on a combination of overshooting top detections and the ERA-Interim reanalysis. Atmos. Res., 198, 34-43, https://doi.org/10.1016/j.atmosres.2017.07.025.

Punkka, A. -J., and M. Bister, 2015: Mesoscale convective systems and their synoptic-scale environment in Finland. Wea. Forecasting, 30, 182-196, https://doi.org/10.1175/WAF-D13-00146.1.

Puskeiler, M., M. Kunz, and M. Schmidberger, 2016: Hail statistics for Germany derived from single-polarization radar data. Atmos. Res., 178-179, 459-470, https://doi.org/10.1016/ j.atmosres.2016.04.014.

Rakov, V. A., and M. A. Uman, 2003: Lightning: Physics and Effects. 1st ed. Cambridge University Press, 734 pp.

Rauhala, J., and D. M. Schultz, 2009: Severe thunderstorm and tornado warnings in Europe. Atmos. Res., 93, 369-380, https:// doi.org/10.1016/j.atmosres.2008.09.026.

Reif, D. W., and H. B. Bluestein, 2017: A 20-year climatology of nocturnal convection initiation over the central and southern Great Plains during the warm season. Mon. Wea. Rev., 145, 1615-1639, https://doi.org/10.1175/MWR-D-16-0340.1.

Renko, T., J. Kuzmić, V. Šoljan, and N. S. Mahović, 2016: Waterspouts in the eastern Adriatic from 2001 to 2013. Nat. Hazards, 82, 441-470, https://doi.org/10.1007/s11069-016-2192-5.

Rodríguez, O., and J. Bech, 2018: Sounding-derived parameters associated with tornadic storms in Catalonia. Int. J. Climatol., 38, 2400-2414, https://doi.org/10.1002/joc.5343.

- , and -2020 : Tornadic environments in the Iberian Peninsula and the Balearic Islands based on ERA5 reanalysis. Int. J. Climatol., https://doi.org/10.1002/joc.6825, in press.

Schaefer, J. T., and R. Edwards, 1999: The SPC tornado/severe thunderstorm database. Preprints, 11th Conf. on Applied Climatology, Dallas, TX, Amer. Meteor. Soc., 603-606.

Schlie, E. E. J., D. Wuebbles, S. Stevens, R. Trapp, and B. Jewett, 2019: A radar-based study of severe hail outbreaks over the contiguous United States for 2000-2011. Int. J. Climatol., 39, 278-291, https://doi.org/10.1002/joc.5805.

Seimon, A., J. T. Allen, T. A. Seimon, S. J. Talbot, and D. K. Hoadley, 2016: Crowdsourcing the El Reno 2013 tornado: A new approach for collation and display of storm chaser imagery for scientific applications. Bull. Amer. Meteor. Soc., 97, 2069-2084, https://doi.org/10.1175/BAMS-D-15-00174.1.

Shapiro, A., E. Fedorovich, and S. Rahimi, 2016: A unified theory for the Great Plains nocturnal low-level jet. J. Atmos. Sci., 73, 3037-3057, https://doi.org/10.1175/JAS-D-15-0307.1.

Shikhov, A., and A. Chernokulsky, 2018: A satellite-derived climatology of unreported tornadoes in forested regions of northeast Europe. Remote Sens. Environ., 204, 553-567, https://doi.org/10.1016/j.rse.2017.10.002.

Sioutas, M. V., 2011: A tornado and waterspout climatology for Greece. Atmos. Res., 100, 344-356, https://doi.org/10.1016/ j.atmosres.2010.08.011.

Smith, B. T., R. L. Thompson, J. S. Grams, C. Broyles, and H. E. Brooks, 2012: Convective modes for significant severe thunderstorms in the contiguous United States. Part I: Storm classification and climatology. Wea. Forecasting, 27, 11141135, https://doi.org/10.1175/WAF-D-11-00115.1.

Surowiecki, A., and M. Taszarek, 2020: A 10-year radar-based climatology of mesoscale convective system archetypes and derechos in Poland. Mon. Wea. Rev., Mon. Wea. Rev., 148, 3471-3488, https://doi.org/10.1175/MWR-D-19-0412.1.

Taszarek, M., and J. Gromadzki, 2017: Deadly tornadoes in Poland from 1820 to 2015. Mon. Wea. Rev., 145, 1221-1243, https:// doi.org/10.1175/MWR-D-16-0146.1.

- and Coauthors, 2019a: A climatology of thunderstorms across Europe from a synthesis of multiple data sources. J. Climate, 32, 1813-1837, https://doi.org/10.1175/JCLI-D-18-0372.1.

— - and Coauthors, 2019b: Derecho evolving from a mesocyclone-A study of 11 August 2017 severe weather outbreak in Poland: Event analysis and high-resolution simulation. Mon. Wea. Rev., 147, 2283-2306, https://doi.org/10.1175/MWR-D-18-0330.1.

, J. T. Allen, T. Púčik, K. Hoogewind, and H. E. Brooks, 2020: Severe convective storms across Europe and the United States. Part II: ERA5 environments associated with lightning, large hail, severe wind and tornadoes. J. Climate, 33, 1026310286, https://doi.org/10.1175/JCLI-D-20-0346.1.

Terti, G., I. Ruin, S. Anquetin, and J. J. Gourley, 2017: A situationbased analysis of flash flood fatalities in the United States. Bull. Amer. Meteor. Soc., 98, 333-345, https://doi.org/10.1175/ BAMS-D-15-00276.1.

Thompson, R. L., R. Edwards, J. A. Hart, K. L. Elmore, and P. Markowski, 2003: Close proximity soundings within supercell environments obtained from the Rapid Update Cycle. Wea. Forecasting, 18, 1243-1261, https://doi.org/10.1175/15200434(2003)018<1243:CPSWSE > 2.0.CO;2.

, B. T. Smith, J. S. Grams, A. R. Dean, and C. Broyles, 2012: Convective modes for significant severe thunderstorms in the contiguous United States. Part II: Supercell and QLCS tornado environments. Wea. Forecasting, 27, 1136-1154, https:// doi.org/10.1175/WAF-D-11-00116.1.

Tippett, M. K., C. Lepore, and J. E. Cohen, 2016: More tornadoes in the most extreme US tornado outbreaks. Science, 354, 14191423, https://doi.org/10.1126/science.aah7393.

Trapp, R. J., D. M. Wheatley, N. T. Atkins, R. W. Przybylinski, and R. Wolf, 2006: Buyer beware: Some words of caution on the use of severe wind reports in postevent assessment and research. Wea. Forecasting, 21, 408-415, https://doi.org/10.1175/WAF925.1.

Trefalt, S., and Coauthors, 2018: A severe hail storm in complex topography in Switzerland-Observations and processes. Atmos. Res., 209, 76-94, https://doi.org/10.1016/j.atmosres.2018.03.007.

van Delden, A., 2001: The synoptic setting of thunderstorms in western Europe. Atmos. Res., 56, 89-110, https://doi.org/ 10.1016/S0169-8095(00)00092-2.

Verbout, S. M., H. E. Brooks, L. M. Leslie, and D. M. Schultz, 2006: Evolution of the U.S. tornado database: 1954-2003. Wea. Forecasting, 21, 86-93, https://doi.org/10.1175/WAF910.1.

Wapler, K., 2017: The life-cycle of hailstorms: Lightning, radar reflectivity and rotation characteristics. Atmos. Res., 193, 6072, https://doi.org/10.1016/j.atmosres.2017.04.009.

— , and P. James, 2015: Thunderstorm occurrence and characteristics in central Europe under different synoptic conditions. Atmos. Res., 158-159, 231-244, https://doi.org/10.1016/ j.atmosres.2014.07.011.

Weber, M. E., J. Y. Cho, J. S. Herd, J. M. Flavin, W. E. Benner, and G. S. Torok, 2007: The next-generation multimission U.S. surveillance radar network. Bull. Amer. Meteor. Soc., 88, 1739-1752, https://doi.org/10.1175/BAMS-88-11-1739. 